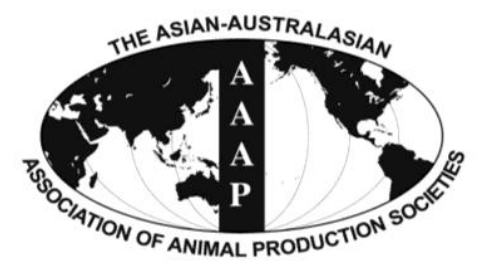

Asian-Aust. J. Anim. Sci.

Vol. 25, No. 6 : 869 - 879

June 2012

www.ajas.info

http://dx.doi.org/10.5713/ajas.2011.11470

\title{
Effects of Dietary Lipid Source and Level on Growth Performance, Blood Parameters and Flesh Quality of Sub-adult Olive Flounder (Paralichthys olivaceus)
}

\author{
Dong-Kyu Kim, Kyoung-Duck Kim, Joo-Young Seo ${ }^{1}$ and Sang-Min Lee* \\ Aquafeed Research Center, National Fisheries Research and Development Institute, Pohang 791-923, Korea
}

\begin{abstract}
This study was conducted to investigate the effects of dietary lipid source and level on growth performance, blood parameters, fatty acid composition and flesh quality of sub-adult olive flounder Paralichthys olivaceus. Eight experimental diets were formulated to contain 5\% squid liver oil (SLO), $5 \%$ linseed oil (LO), $5 \%$ soybean oil (SO), a mixture of $1 \%$ squid liver oil, $2 \%$ linseed oil and 2\% soybean oil (MIX), no lipid supplementation with high protein level (LL-HP), $10 \%$ squid liver oil (HL-SLO), a mixture of $1 \%$ squid liver oil, $4.5 \%$ linseed oil and $4.5 \%$ soybean oil (HL-VO), and $1 \%$ squid liver oil with high starch level (LL-HC), respectively. Two replicate groups of fish (average initial weight of $296 \mathrm{~g}$ ) were fed the diets for 17 wks. After 5 wks, 11 wks and the end of the feeding trial, five fish from each tank were randomly sampled for analysis of body composition. At the end of the feeding trial, final mean weight of fish fed the LL-HP diet was significantly $(\mathrm{p}<0.05)$ higher than that of fish fed the HL-VO diet, but did not differ significantly from those of fish fed the SLO, LO, SO, MIX, HL-SLO and LL-HC diets. Fish fed the LL-HP diet showed significantly higher feed efficiency than fish fed the LO, HL-SLO and HL-VO diets. Feed efficiency of fish fed the LO, SO and MIX diets were similar to those of fish fed the SLO and HL-SLO diets. Fish fed the HL-SLO diet showed significantly higher total cholesterol content in plasma compared with other diets. Fatty acid composition of tissues was reflected by dietary fatty acid composition. The highest linoleic (LA) and linolenic acid (LNA) contents in the dorsal muscle were observed in fish fed the SO and LO diets, respectively, regardless of feeding period. The highest eicosapentaenoic acid (EPA) content in the dorsal muscle was observed in fish fed the LL-HP and LL-HC diets after 11 and 17 weeks of feeding, respectively. Fish fed the SLO and HL-SLO diets showed higher docosahexaenoic acid (DHA) content than that of other treatments after 11 and 17 weeks of feeding, respectively. Dietary inclusion of vegetable oils reduced n-3 HUFA contents in the dorsal muscle and liver of fish. The n-3 HUFA contents in tissues of fish fed the SLO and HL-SLO diets were higher than those of fish fed other diets, except for the LL-HP and LL-HC diets. Hardness, gel strength, chewiness and cohesiveness values of dorsal muscle in fish were significantly affected by dietary lipid source. The results of this study indicate that fish oil in fish meal based diets for sub-adult olive flounder could be replaced by soybean oil and linseed oil without negative effects on growth and feed utilization. (Key Words: Dietary Lipid, Olive Flounder, Paralichthys olivaceus, Fatty Acid, Flesh Quality)
\end{abstract}

\section{INTRODUCTION}

Lipids play important physiological roles in providing energy, essential fatty acids and fat soluble nutrients for normal growth and development of fish. Deficiency of dietary lipid may increase the use of protein for energy and result in the increase of ammonia excretion and thus water

\footnotetext{
* Corresponding Author: Sang-Min Lee. Department of Marine Bioscience and Technology, Gangneung-Wonju National University, Gangneung 210-702, Korea. Tel: +82-33-640-2414, Fax: +82-33-640-2955, E-mail: smlee@gwnu.ac.kr

${ }^{1}$ Gangwon Province Deep Ocean Water \& Fishery Resource Center, Goseong 219-812, Korea.

Submitted Dec. 6, 2011; Accepted Jan. 31, 2012; Revised Mar. 4, 2012
}

pollution (Kaushik and Cowey, 1991). On the contrary, excessive dietary lipid was reported to reduce feed intake and growth performance of several fish species (Peres and Oliva-Teles, 1999; Regost et al., 2003; Kim et al., 2006). Kim et al. (2006) reported that daily feed intake of olive flounder significantly decreased with the increase of dietary lipid. High inclusion of fish oil can also result in increased feed costs and reduced profits in the aquaculture industry.

Fish oil, because of its high content of essential fatty acids, is used as a main lipid source in marine fish feeds. Recently, the rapid expansion of food animal growing industries has included aquaculture, which is concomitant with the global decline of fisheries production because of over-fishing resulting in a shortage and subsequent 
increased price of fish oil (Sargent and Tacon, 1999). To sustain aquaculture development, many studies have been conducted to indentify alternative lipid sources (Caballero et al., 2002; Glencross et al., 2003; Izquierdo et al., 2005; Mourente and Bell, 2006; Lin and Shiau, 2007; Piedecausa et al., 2007). Vegetable oils such as soybean, linseed and rapeseed oils have shown promise as alternatives for fish oil. Piedecausa et al. (2007) reported that dietary fish oil could be partially replaced by vegetable oils without any adverse effects on feed intake and growth of sharp snout seabream. In another example of total replacement of dietary fish oil, canola oil did not affect growth performance of juvenile red sea bream (Glencross et al., 2003).

Dietary inclusion of vegetable oils were reported to reduce $n-3$ fatty acid composition, particularly eicosapentaenoic acid (EPA, 20:5n-3) and doxosahexaenoic acid (DHA, 22:6n-3) (Hillestad and Johnsen, 1994; Montero et al., 2005; Fountoulaki et al., 2009) which are important for human nutrition and flesh quality of farmed fish (Izquierdo et al., 2005; Fountoulaki et al., 2009). Montero et al. (2005) found that flesh contents of n-3 highly unsaturated fatty acids (HUFA) was reduced to $45 \%$ and $50 \%$ through dietary fish oil replacement by $60 \%$ rapeseed, linseed or soybean oil, and by $80 \%$ linseed oil, respectively. Changes in organoleptic parameters and flavour of flesh were also observed in fish fed diets containing high inclusion level of soybean and linseed oil (Izquierdo et al., 2005).

The olive flounder is the most important marine cultured fish species in Korea due to its fast growth and high demand as sashimi. Recently, due to the shortage and increased fish oil prices, fish feed manufacturers are looking for alternative lipid sources originating from plants such as soybean and linseed oils to reduce production costs. However, growth and feed utilization responses of flounder when fed these lipid sources have not been examined. This study investigate the effects of dietary soybean, linseed oil and a blend of these lipid sources with fish oil on growth performance, blood parameters, fatty acid composition and flesh quality of olive flounder.

\section{MATERIALS AND METHODS}

\section{Experimental diets}

Ingredients and proximate composition of the experimental diets are presented in Table 1. In order to investigate the utilization of the different source and level of plant oil as fish oil replacer, eight diets were formulated to contain 5\% squid liver oil (SLO), $5 \%$ linseed oil (LO), $5 \%$ soybean oil (SO), a mixture of $1 \%$ squid liver oil, $2 \%$ linseed oil and 2\% soybean oil (MIX), no lipid supplement with high protein content (LL-HP), $10 \%$ squid liver oil (HL-SLO), a mixture of $1 \%$ squid liver oil, $4.5 \%$ linseed oil and $4.5 \%$ of soybean oil (HL-VO), and $1 \%$ squid liver oil with $11 \%$ alpha-starch (LL-HC), respectively. Fish meal and wheat flour were used as the main protein and carbohydrate sources, respectively. The ingredients of the experimental diets were mechanically mixed with distilled water at the ratio of $100 \mathrm{~g}$ of ingredient mixture to 35 to 40 $\mathrm{g}$ of water, and pressure-pelleted using a laboratory pellet machine. All diets were dried at room temperature for $48 \mathrm{~h}$, and stored at $-30^{\circ} \mathrm{C}$ until used. Fatty acid composition of dietary lipid sources and the experimental diets are presented in Table 2 and 3, respectively.

\section{Experimental fish and feeding trial}

Olive flounder (Paralichthys olivaceus) were obtained from a local fish farm (Uljin, Korea) and acclimated to experimental tanks for 4 wks before the feeding trial. Fish $(296 \pm 2.8 \mathrm{~g})$ were randomly distributed in sixteen $1,200 \mathrm{~L}$ tanks at a density of 25 per tank in a flow through system. Two replicate groups of fish were hand-fed one of the experimental diets to apparent satiation once a day (09:00 h) for 17 wks. Seawater was supplied to each tank at a flow rate of $20 \mathrm{~L} / \mathrm{min}$. Mean water temperature was at $21.5 \pm 5.5^{\circ} \mathrm{C}$, and the photoperiod followed the natural condition (12 h:12 h/dark:night) during the feeding trial.

\section{Sampling procedures and chemical analysis}

At the beginning, after $5 \mathrm{wks}, 11 \mathrm{wks}$ and the end of the feeding trial, all fish in a tank were starved for $24 \mathrm{~h}$, and five fish from each tank were randomly sampled after being anesthetized with MS222 solution at a concentration of 100 ppm for analysis of body composition. At the end of the feeding trial, five fish from each tank were used for proximate composition, fatty acids composition and blood chemistry. Total length, body weight, liver weight and intestine weight of five fish from each tank were measured. Blood was taken from the caudal vein of each specimen using heparinized syringes. Plasma was collected after centrifugation at $3,500 \mathrm{rpm}$ for $10 \mathrm{~min}$ and stored at $-70^{\circ} \mathrm{C}$ for biochemical analysis. Total plasma protein, glucose, glutamate oxaloacetate transaminase (GOT) and cholesterol concentrations were determined using an automatic analyzer (Toshiba-200FR, Tokyo, Japan). Proximate composition of the diets was determined according to standard methods (AOAC, 1995). Crude protein was determined by Kjeldahl method using the Kjeldahl System (Buchi, Flawil, Switzerland). Crude lipid was with ether extracted in a soxhlet extractor (SER 148, VELP Scientifica, Milano, Italy), and moisture was determined using a dry oven at $105^{\circ} \mathrm{C}$ for $6 \mathrm{~h}$. Ash content was determined after combustion at $600^{\circ} \mathrm{C}$ for $4 \mathrm{~h}$ in a muffle furnace. Gross energy content was measured using an adiabatic bomb calorimeter (Parr 1356, Moline, IL, USA). Lipid for fatty acid analysis was extracted by a mixture of chloroform and 
Table 1. Ingredients and nutrient content of the experiment diets

\begin{tabular}{|c|c|c|c|c|c|c|c|c|}
\hline & \multicolumn{8}{|c|}{ Diets } \\
\hline & SLO & LO & $\mathrm{SO}$ & MIX & LL-HP & HL-SLO & HL-VO & LL-HC \\
\hline \multicolumn{9}{|l|}{ Ingredients (\%) } \\
\hline Fish meal $^{1}$ & 50.0 & 50.0 & 50.0 & 50.0 & 63.0 & 50.0 & 50.0 & 52.0 \\
\hline Wheat flour & 27.71 & 27.71 & 27.71 & 27.71 & 19.71 & 22.71 & 22.71 & 18.71 \\
\hline Dehulled soybean meal & 7.0 & 7.0 & 7.0 & 7.0 & 7.0 & 7.0 & 7.0 & 7.0 \\
\hline Alpha-starch & & & & & & & & 11.0 \\
\hline Wheat gluten & 5.0 & 5.0 & 5.0 & 5.0 & 5.0 & 5.0 & 5.0 & 5.0 \\
\hline Beer yeast & 2.0 & 2.0 & 2.0 & 2.0 & 2.0 & 2.0 & 2.0 & 2.0 \\
\hline Squid liver oil & 5.0 & & & 1.0 & & 10.0 & 1.0 & 1.0 \\
\hline Linseed oil & & 5.0 & & 2.0 & & & 4.5 & \\
\hline Soybean oil & & & 5.0 & 2.0 & & & 4.5 & \\
\hline Vitamin premix ${ }^{2}$ & 1.5 & 1.5 & 1.5 & 1.5 & 1.5 & 1.5 & 1.5 & 1.5 \\
\hline Mineral premix ${ }^{3}$ & 1.5 & 1.5 & 1.5 & 1.5 & 1.5 & 1.5 & 1.5 & 1.5 \\
\hline Choline chloride & 0.1 & 0.1 & 0.1 & 0.1 & 0.1 & 0.1 & 0.1 & 0.1 \\
\hline DL- $\alpha$-tocopheryl acetate & 0.04 & 0.04 & 0.04 & 0.04 & 0.04 & 0.04 & 0.04 & 0.04 \\
\hline Vitamin $C^{4}$ & 0.15 & 0.15 & 0.15 & 0.15 & 0.15 & 0.15 & 0.15 & 0.15 \\
\hline \multicolumn{9}{|c|}{ Nutrient contents (dry matter basis) } \\
\hline Dry matter $(\%)$ & 74.9 & 77.5 & 75.9 & 77.3 & 72.8 & 79.6 & 77.7 & 73.2 \\
\hline Crude protein $(\%)$ & 50.4 & 48.4 & 47.9 & 48.4 & 60.6 & 46.3 & 47.8 & 49.3 \\
\hline Crude lipid (\%) & 10.6 & 10.6 & 10.6 & 9.8 & 5.6 & 14.1 & 15.5 & 5.0 \\
\hline $\operatorname{Ash}(\%)$ & 9.6 & 9.7 & 9.7 & 9.6 & 11.9 & 9.7 & 9.5 & 9.8 \\
\hline Energy $(\mathrm{kcal} / \mathrm{g})$ & 5.1 & 5.0 & 5.2 & 4.9 & 4.9 & 5.3 & 5.3 & 4.7 \\
\hline n-3 HUFA $^{5}$ & 3.4 & 2.5 & 2.6 & 2.4 & 1.8 & 4.6 & 3.9 & 1.6 \\
\hline
\end{tabular}

${ }^{1}$ Provided by Fisheries Co-op Feeds Co., Ltd. Gyeongsannam province, Korea.

${ }^{2}$ Vitamin premix contained the following amount which was diluted in cellulose (g/kg premix): L-ascorbic acid, 121.2; DL- $\alpha$-tocopheryl acetate, 18.8; thiamin hydrochloride, 2.7; riboflavin, 9.1; pyridoxine hydrochloride, 1.8; niacin, 36.4; Ca-D-pantothenate, 12.7; myo-inositol, 181.8; D-biotin, 0.27; folic acid, 0.68; p-aminobenzoic acid, 18.2; menadione, 1.8; retinyl acetate, 0.73 ; cholecalciferol, 0.003 ; cyanocobalamin, 0.003 .

${ }^{3}$ Mineral premix contained the following ingredients (g/kg premix): $\mathrm{MgSO}_{4} 7 \mathrm{H}_{2} \mathrm{O}, 80.0 ; \mathrm{NaH}_{2} \mathrm{PO}_{4} \cdot 2 \mathrm{H}_{2} \mathrm{O}, 370.0 ; \mathrm{KCl}_{1}, 130.0 ; \mathrm{Ferric}$ citrate, 40.0; $\mathrm{ZnSO}_{4} \cdot 7 \mathrm{H}_{2} \mathrm{O}, 20.0$; Ca-lactate, 356.5; $\mathrm{CuCl}, 0.2 ; \mathrm{AlCl}_{3} \cdot 6 \mathrm{H}_{2} \mathrm{O}, 0.15 ; \mathrm{KI}, 0.15 ; \mathrm{Na}_{2} \mathrm{Se}_{2} \mathrm{O}_{3}, 0.01 ; \mathrm{MnSO}_{4} \cdot \mathrm{H}_{2} \mathrm{O}, 2.0 ; \mathrm{CoCl}_{2} \cdot 6 \mathrm{H}_{2} \mathrm{O}, 1.0$.

${ }^{4}$ ROVIMIX ${ }^{\circledR}$ STAY-C ${ }^{\circledR} 35$. DSM Nutrition Ltd. Seocho-ku, Korea.

${ }^{5}$ Highly unsaturated fatty acids $(\mathrm{C} \geq 20)$, calculated (dietary total lipid \%×area \%×0.892). (Yoshimatsu et al., 1997).

Table 2. Fatty acid composition (\% of total fatty acids) of dietary lipid sources

\begin{tabular}{lrcc}
\hline & Squid liver oil & Soybean oil & Linseed oil \\
\hline Fatty acids & & & \\
C14:0 & 2.6 & 0.1 & 0.1 \\
C16:0 & 13.5 & 13.4 & 6.1 \\
C16:1 & 4.3 & & \\
C18:0 & 1.7 & 1.5 & 1.2 \\
C18:1n-9 & 16.6 & 13.0 & 15.2 \\
C18:2n-6 & 1.0 & 63.8 & 19.1 \\
C18:3n-3 & 1.0 & 8.3 & 57.7 \\
C20:1n-9 & 11.1 & & 0.6 \\
C20:2n-6 & 1.7 & & \\
C20:3n-3 & 0.3 & & \\
C20:4n-6 & 0.6 & & \\
C20:5n-3 & 11.3 & & \\
C22:1n-9 & 7.4 & & \\
C22:3n-3 & 0.6 & & \\
C22:5n-3 & 1.2 & & \\
C22:6n-3 & 25.1 & & \\
\hline
\end{tabular}

methanol $(2: 1, \mathrm{v} / \mathrm{v})$ according to the method of Folch et al. (1957). The fatty acid composition was determined after methylation with $14 \% \mathrm{BF}_{3}$ methanol (Sigma, St Louis, MO, USA) by gas chromatography (HP-6890 PLUS GC, Hewlett-Packard, Palo Alto, CA, USA) with a flame ionization detector, equipped with $\mathrm{SP}^{\mathrm{TM}}-2560$ capillary column $(100 \mathrm{~m} \times 0.25 \mathrm{~mm}$ i.d., film thickness $0.20 \mu \mathrm{m}$; Supelco, Bellefonte, PA, USA). Injector and detector temperatures were $260^{\circ} \mathrm{C}$. The column temperature was programmed from $140^{\circ} \mathrm{C}$ to $240^{\circ} \mathrm{C}$ at a rate of $4^{\circ} \mathrm{C} / \mathrm{min}$. Helium was used as the carrier gas. Fatty acids were identified by comparison with retention times of the known standard fatty acid methyl esters.

\section{Physical properties of flesh}

Three fish per tank were sampled and kept at $4{ }^{\circ} \mathrm{C}$ in a refrigerator for physical properties analysis. Flesh in the upper dorsal muscle was filleted and trimmed in square pieces at a dimension of $2 \times 2 \mathrm{~cm}^{2}$. Texture parameters including hardness, gel strength, texture, cohesiveness, chewiness and breaking strength were measured using a 
Table 3. Fatty acid composition (\% of total fatty acids) of the experimental diets

\begin{tabular}{lrrrrrrrr}
\hline & \multicolumn{7}{c}{ Diets } \\
\cline { 2 - 9 } & \multicolumn{1}{c}{ SLO } & LO & SO & MIX & LL-HP & HL-SLO & HL-VO & LL-HC \\
\hline Fatty acids & & & & & & & & \\
C14:0 & 3.2 & 2.6 & 2.7 & 2.7 & 3.8 & 3.0 & 2.3 & 3.8 \\
C16:0 & 21.5 & 18.4 & 20.3 & 20.3 & 23.0 & 21.3 & 19.1 & 22.1 \\
C16:1 & 4.8 & 3.7 & 3.9 & 4.0 & 5.4 & 4.6 & 3.6 & 5.3 \\
C18:0 & 3.8 & 3.8 & 3.9 & 4.1 & 4.3 & 4.0 & 2.3 & 4.1 \\
C18:1n-9 & 13.5 & 14.4 & 14.7 & 14.8 & 12.8 & 14.2 & 15.0 & 13.2 \\
C18:2n-6 & 12.4 & 14.9 & 22.3 & 17.4 & 10.2 & 9.9 & 18.2 & 10.5 \\
C18:3n-3 & 1.2 & 13.9 & 2.5 & 6.6 & 1.0 & 1.1 & 9.2 & 1.1 \\
C20:1n-9 & 2.3 & 0.8 & 0.9 & 1.2 & 1.2 & 3.4 & 1.0 & 1.7 \\
C20:2n-6 & 0.8 & 0.5 & 0.5 & 0.6 & 0.7 & 0.9 & 0.5 & 0.7 \\
C20:4n-6 & 0.5 & 0.4 & 0.4 & 0.4 & 0.5 & 0.5 & 0.4 & 0.6 \\
C20:5n-3 & 15.3 & 11.8 & 12.3 & 12.2 & 16.7 & 14.5 & 11.9 & 16.3 \\
C22:1n-9 & 0.4 & 0.4 & 0.4 & 0.2 & 0.6 & 0.1 & 0.5 & 0.6 \\
C22:3n-3 & 0.3 & 0.2 & 0.2 & 0.2 & 0.3 & 0.4 & 0.3 & 0.3 \\
C22:5n-3 & 3.0 & 2.6 & 2.7 & 2.7 & 3.5 & 3.1 & 2.7 & 3.5 \\
C22:6n-3 & 17.1 & 11.5 & 12.2 & 12.7 & 15.9 & 18.8 & 13.2 & 16.2 \\
n-3 HUFA & 35.7 & 26.2 & 27.4 & 27.9 & 36.5 & 36.8 & 28.0 & 36.3 \\
\hline
\end{tabular}

${ }^{1}$ Highly unsaturated fatty acid $(\mathrm{C} \geq 20)$.

Texture Analyzer (COMPAC-100, Tokyo, Japan).

\section{Statistical analysis}

Data were subjected to one-way analysis of variance (ANOVA) to test the effects of dietary lipid source and level on growth performance, feed utilization and fatty acid composition of fish. When significant differences $(\mathrm{p}<0.05)$ were found in one-way ANOVA, Duncan's multiple range test (Duncan, 1955) was used to rank the groups. All references to significant differences indicate $\mathrm{p}<0.05$. All statistical analyses were performed using SPSS program Version 14.0 for Windows (SPSS Michigan Avenue, Chicago, IL, USA). Data are presented are as mean \pm SE of two replications.

\section{RESULTS AND DISCUSSION}

Growth performance and morphological parameters of olive flounder fed with experimental diets are presented in Table 4. Survival was not significantly different among

Table 4. Growth performance and morphological parameters of sub-adult olive flounder fed the experimental diets for 17 wks

\begin{tabular}{|c|c|c|c|c|c|c|c|c|}
\hline & \multicolumn{8}{|c|}{ Diets } \\
\hline & SLO & LO & $\mathrm{SO}$ & MIX & LL-HP & HL-SLO & HL-VO & LL-HC \\
\hline$\overline{\mathrm{IMW}(\mathrm{g})^{1}}$ & $297 \pm 3.0$ & $296 \pm 1.6$ & $290 \pm 1.8$ & $295 \pm 5.4$ & $296 \pm 4.6$ & $299 \pm 6.8$ & $303 \pm 0.1$ & $292 \pm 0.1$ \\
\hline Survival (\%) & $92 \pm 4.0$ & $82 \pm 6.0$ & $96 \pm 4.0$ & $76 \pm 8.0$ & $92 \pm 4.0$ & $74 \pm 14.0$ & $86 \pm 2.0$ & $88 \pm 8.0$ \\
\hline $\mathrm{FMW}(\mathrm{g})^{2}$ & $519 \pm 9.1^{\mathrm{ab}}$ & $507 \pm 13.5^{\mathrm{ab}}$ & $523 \pm 19.6^{a b}$ & $568 \pm 59.3^{\mathrm{ab}}$ & $624 \pm 44.4^{b}$ & $573 \pm 58.7^{\mathrm{ab}}$ & $455 \pm 0.5^{\mathrm{a}}$ & $554 \pm 28.9^{\mathrm{ab}}$ \\
\hline $\mathrm{FE}(\%)^{3}$ & $71 \pm 0.9^{\mathrm{ab}}$ & $51 \pm 8.6^{\mathrm{a}}$ & $80 \pm 13.3^{\mathrm{ab}}$ & $67 \pm 0.8^{\mathrm{ab}}$ & $98 \pm 0.9^{\mathrm{b}}$ & $59 \pm 3.9^{\mathrm{a}}$ & $53 \pm 1.3^{\mathrm{a}}$ & $93 \pm 20.3^{b}$ \\
\hline $\operatorname{PER}(\%)^{4}$ & $1.41 \pm 0.01^{\mathrm{ab}}$ & $1.10 \pm 0.20^{\mathrm{a}}$ & $1.72 \pm 0.30^{\mathrm{ab}}$ & $1.45 \pm 0.01^{\mathrm{ab}}$ & $1.60 \pm 0.01^{\mathrm{ab}}$ & $1.38 \pm 0.01^{\mathrm{ab}}$ & $1.13 \pm 0.01^{\mathrm{a}}$ & $1.97 \pm 0.04^{b}$ \\
\hline DFI $(\%)^{5}$ & $0.60 \pm 0.01$ & $0.75 \pm 0.15$ & $0.60 \pm 0.10$ & $0.70 \pm 0.10$ & $0.55 \pm 0.05$ & $0.70 \pm 0.01$ & $0.65 \pm 0.05$ & $0.60 \pm 0.10$ \\
\hline DPI $(\%)^{6}$ & $0.30 \pm 0.01$ & $0.35 \pm 0.05$ & $0.35 \pm 0.05$ & $0.35 \pm 0.05$ & $0.35 \pm 0.05$ & $0.30 \pm 0.01$ & $0.30 \pm 0.01$ & $0.25 \pm 0.05$ \\
\hline $\mathrm{CF}^{7}$ & $1.2 \pm 0.07$ & $1.1 \pm 0.04$ & $1.2 \pm 0.00$ & $1.1 \pm 0.04$ & $1.2 \pm 0.03$ & $1.2 \pm 0.04$ & $1.2 \pm 0.09$ & $1.2 \pm 0.01$ \\
\hline $\mathrm{HSI}^{8}$ & $2.8 \pm 0.2^{\mathrm{cd}}$ & $2.3 \pm 0.3^{\mathrm{bc}}$ & $2.6 \pm 0.4^{\mathrm{abc}}$ & $2.0 \pm 0.2^{\mathrm{a}}$ & $2.1 \pm 0.1^{\mathrm{a}}$ & $3.1 \pm 0.1^{\mathrm{d}}$ & $2.7 \pm 0.1^{\mathrm{cd}}$ & $1.9 \pm 0.1^{\mathrm{a}}$ \\
\hline VSI $^{9}$ & $2.2 \pm 0.2$ & $2.5 \pm 0.3$ & $2.0 \pm 0.1$ & $2.1 \pm 0.1$ & $2.4 \pm 0.2$ & $2.2 \pm 0.3$ & $2.2 \pm 0.1$ & $2.1 \pm 0.1$ \\
\hline
\end{tabular}

Values (mean \pm SE of replications) in the same column not sharing a common superscript are significantly different ( $p<0.05$ ).

${ }^{1}$ Initial mean weight. ${ }^{2}$ Final mean weight. ${ }^{3}$ Feed efficiency $(\%)=$ Fish wet weight gain $(\mathrm{g}) \times 100 /$ feed intake $(\mathrm{g}$, dry matter)

${ }^{4}$ Protein efficiency ratio $=$ Fish wet weight gain $(\mathrm{g}) /$ protein intake $(\mathrm{g})$.

${ }^{5}$ Daily feed intake $(\%)=$ Feed intake $(\mathrm{g}$, dry matter $) \times 100 /(($ initial fish weight $(\mathrm{g})+$ final fish weight $(\mathrm{g})+\mathrm{dead}$ fish weight $(\mathrm{g})) / 2 \times$ days fed $)$.

${ }^{6}$ Daily protein intake $(\%)=$ Protein intake $(\mathrm{g}) \times 100 /(($ initial fish weight $(\mathrm{g})+$ final fish weight $(\mathrm{g})+\mathrm{dead}$ fish weight $(\mathrm{g})) / 2 \times \mathrm{days}$ fed $)$.

${ }^{7}$ Condition factor $=$ Fish weight $(\mathrm{g}) \times 100 /$ fish length $(\mathrm{cm})^{3} .{ }^{8}$ Hepatosomatic index $=$ Liver weight $\times 100 /$ body weight.

${ }^{9}$ Visceralsomatic index $=$ Viscera weight $\times 100$ /body weight. 
dietary treatments. Final mean weight of fish fed the LL-HP diet was significantly higher than that of fish fed the HLVO diet $(\mathrm{p}<0.05)$, but was not significantly different from that of fish fed the other diets. Fish fed the LL-HP and LL$\mathrm{HC}$ diets showed significantly higher feed efficiency than fish fed the LO, HL-SLO and HL-VO diets $(p<0.05)$. Protein efficiency ratio of fish fed the LL-HC diet was significantly higher than that of fish fed the LO and HL-VO diets $(\mathrm{p}<0.05)$, but was not significantly different from that of fish fed the other diets. Daily feed intake and daily protein intake were not affected by dietary treatments.

The results of this study suggest that total replacement of SLO by LO, SO, and a blend of SLO, LO and SO in fish meal-based diets did not affect growth and feed intake of olive flounder. Due to the shortage and gradual price increase of fish oil, recent studies (Izquierdo et al., 2005; Mourente and Bell, 2006; Francis et al., 2007; Piedecausa et al., 2007; Peng et al., 2008) have attempted to investigate the use of vegetable oils as alternatives to fish oil in fish feeds. Recent research results have shown that the use of vegetable oils causes species-specific responses. For sharp snout seabream (Piedecausa et al., 2007) and turbot (Regost et al., 2003), no adverse effects on growth performance and feed utilization were observed when fed diets in which total fish oil was replaced by LO and SO, respectively. However, other studies reported that high dietary inclusion of vegetable oils impaired growth and feed utilization in Atlantic salmon (Bell et al., 2004; Torstensen et al., 2005), black seabream (Peng et al., 2008) and European seabass (Montero et al., 2005), gilthead seabream (Izquierdo et al., 2005).

Dietary ingredients, particularly fish meal, could affect the outcome of replacement of fish oil by high inclusion levels of vegetable oils. Kim et al. (2002) reported that substitution of SLO by SO and a blend of LO and SO in the diets containing defatted fish meal significantly affected growth rate, blood biochemical parameters and hepatic microstructure of juvenile olive flounder. The proper dietary inclusion level of fish meal could enhance palatability and acceptability and consequently increase growth performance and feed efficiency of olive flounder (Deng et al., 2006). The increase of dietary fish meal content has also been reported to improve biological values in fish (Pimental-
Rodribues and Oliva-Teles, 2007). Kim et al. (2006) reported the best weight gain and feed efficiency in flounder when fed a diet containing high fish meal level $(57 \%)$. Lee et al. (2000) and Deng et al. (2006) observed that juvenile olive flounder grew faster when fed a diet containing low lipid and high fish meal contents. A similar result of good growth in fish fed LL-HP diet containing high fish meal level was also observed in this study.

Lower growth rate and feed efficiency observed in olive flounder fed the HL-VO diet compared to that of fish fed other diets are likely due to an excessive dietary content of vegetable oils. Studies (Seo et al., 2005; Abimorad and Carneiro, 2007) have reported that a high inclusion level of vegetable oils could negatively affect dietary nutrient digestibilities and result in lower feed efficiency and weight gain of fish. Seo et al. (2005) found that dry matter, carbohydrate and energy digestibilities of olive flounder fed a diet containing a high lipid level were lower than those fed high protein diets. Lee et al. (2000) reported that increasing dietary lipid levels decreased growth of juvenile olive flounder. Another reason for the low growth in HLVO diet is probably due to an imbalance of fatty acid composition, especially a high level of LA. A similar result was reported for turbot (Regost et al., 2003). Although fish oil and phospholipids in fish meal were sufficient to meet essential fatty acids requirements in the SO and LO diet for turbot, turbot fed high vegetable oil diets had lower growth. This result may be due to the inability of some marine fish species to synthesize EPA and DHA from C18 series such as linolenic acid in vegetable oil. Therefore, marine fish do depend on the n-3 series content in their basal diet. Consequently, we must carefully consider the effect on fish growth when replacing a proportion dietary fish oil with vegetable oil (Regost et al., 2003).

Hepatosomatic index of fish fed the SLO, LO, HL-SLO and HL-VO diets was significantly higher than that of fish fed the MIX, LL-HP and LL-HC diets $(p<0.05)$. This phenomenon may be due to change of lipid composition in diets. Dietary lipid sources and levels did not affect the condition factor and visceralsomatic index.

Plasma contents of total protein, glucose and glutamicoxlaoacetic acid transaminase (GOT) were not significantly affected by dietary lipid source and level (Table 5). Fish fed

Table 5. Plasma biochemical parameters of sub-adult olive flounder fed the experimental diets for $17 \mathrm{wks}$

\begin{tabular}{|c|c|c|c|c|c|c|c|c|}
\hline & \multicolumn{8}{|c|}{ Diets } \\
\hline & SLO & LO & SO & MIX & LL-HP & HL-SLO & HL-VO & LL-HC \\
\hline Total protein $(\mathrm{g} / 100 \mathrm{ml})$ & $4.2 \pm 0.1$ & $3.8 \pm 0.3$ & $3.9 \pm 0.2$ & $3.5 \pm 0.1$ & $3.7 \pm 0.1$ & $4.0 \pm 0.1$ & $3.7 \pm 0.1$ & $3.6 \pm 0.1$ \\
\hline Glucose (mg/100 ml) & $17.5 \pm 2.1$ & $17.5 \pm 0.7$ & $17.5 \pm 0.7$ & $19.5 \pm 3.5$ & $20.0 \pm 0.1$ & $18.5 \pm 0.7$ & $17.0 \pm 0.1$ & $17.0 \pm 1.4$ \\
\hline $\begin{array}{l}\text { Total cholesterol } \\
(\mathrm{mg} / 100 \mathrm{ml})\end{array}$ & $326 \pm 28.5^{\mathrm{c}}$ & $237 \pm 11.5^{\mathrm{ab}}$ & $245 \pm 3.5^{\mathrm{b}}$ & $236 \pm 0.5^{\mathrm{ab}}$ & $257 \pm 5.5^{\mathrm{b}}$ & $458 \pm 17.0^{\mathrm{d}}$ & $247 \pm 1.5^{\mathrm{b}}$ & $202 \pm 0.5^{\mathrm{a}}$ \\
\hline GOT (IU/L) $)^{1}$ & $5.0 \pm 0.1$ & $4.5 \pm 0.7$ & $3.5 \pm 0.7$ & $4.0 \pm 0.1$ & $4.0 \pm 1.4$ & $4.5 \pm 0.7$ & $5.0 \pm 0.1$ & $4.5 \pm 0.7$ \\
\hline
\end{tabular}

Values (mean \pm SE of replications) in the same column not sharing a common superscript are significantly different ( $<<0.05)$.

${ }^{1}$ Glutamic-oxlaoacetic acid transaminase. 
the SLO and HL-SLO diets showed a higher total cholesterol content in comparison with that of fish fed other diets. Total cholesterol of fish fed the HL-SLO diet was higher than that of fish fed the SLO diet. Decreasing the total cholesterol of fish fed a diet containing vegetable oils has not been well established. In this study, a lower cholesterol content in fish fed diets containing high vegetable oils was likely related to cholesterol lowering factors such as phytosterol and oleic acid, linoleic acid (LA) and linolenic acid (LNA) present in linseed and soybean oils. Richard et al. (2006) and Peng et al. (2008) reported that European seabass and black seabeam fed diets containing vegetable oils showed a lower cholesterol content compared to fish fed a fish oil diet. Whereas, other studies (Dannevig and Norum, 1982; Este'vez et al., 1996; Gilman et al., 2003) have shown that the presence of phytosterol in vegetable oils can affect absorption and metabolism of cholesterol in fish.

In the results of this study, crude lipid content in dorsal muscle of fish was not significantly affected by dietary lipid source and level. Similar results were reported for turbot and sharp snout seabream (Regost et al., 2003; Piedecausa et al., 2007), whereas in other studies dietary lipid source and level did influence the body composition of fish (Peng et al., 2008).

Fatty acid composition in the dorsal muscle of olive flounder is presented in Table 6. The highest LA and LNA content in the dorsal muscle were observed in fish fed the SO and LO diets after 5, 11 and 17 wks, respectively. The LA content of fish fed diets containing soybean oil (SO, MIX and HL-VO) after 11 and 17 wks was significantly higher than that of fish after 5 wks (Figure 1). The LNA content of the dorsal muscle in fish fed diets containing linseed oil (LO, MIX and HL-VO) after 11 and 17 wks was significantly higher than that of fish after 5 wks (Figure 2). Similar results were observed in fatty acid composition of LA and LNA in the liver. Arachidonic acid (ARA) content in the dorsal muscle was not significantly different among dietary treatments after 5, 11 and 17 wks of feeding. The EPA content in the dorsal muscle was not affected by dietary treatments after 5 wks of feeding, whereas the highest EPA content in the dorsal muscle was observed in fish fed the LL-HP and LL-HC diets after 11 and $17 \mathrm{wks}$, respectively (Figure 3). DHA content in the dorsal muscle tended to decrease after 11 and 17 wks of feeding compared to after 5 wks of feeding except for MIX and HL-SLO diets. (Figure 4).

Fatty acid composition in the liver of olive flounder is presented in Table 7. The highest LA and LNA contents in the liver were observed in fish fed the SO and LO diets after 5, 11 and 17 wks, respectively. EPA content in the liver was affected by dietary lipid source and level for 5 and 11 wks of feeding, but was not different among dietary groups after
17 wks of feeding. DHA content in the liver of flounder fed the SLO and HL-SLO diets was higher than that of fish fed the other diets after 5, 11 and 17 wks of feeding. Dietary inclusion of vegetable oils reduced n-3 HUFA contents in the liver.

The results of this study indicated that the fatty acid composition in the dorsal muscle and liver significantly reflected the fatty acid composition of the experimental diets. The content of n-3 HUFA significantly decreased in fish fed the diets containing vegetable oils. This was similar to the results reported for other marine fish species such as Atlantic salmon, gilthead seabream, European seabass, sharp snout seabream and black seabream (Bell et al., 2004; Izquierdo et al., 2005; Mourente and Bell, 2006; Piedecausa et al., 2007; Peng et al., 2008). In this study, DHA content was significantly higher than EPA in fish tissues tested. This suggests that DHA may be more preferentially accumulated in tissues compared with EPA. Similar results were also reported in another flounder study (Kim and Lee, 2004) and other marine fish species (Menoyo et al., 2004). Herzberg et al. (1996) reported that EPA was oxidized faster than DHA by muscle and liver homogenates. Consequently, the faster peroxidation rate of EPA may also contribute to the reduction of its content (Bell et al., 2001).

Physical properties of the dorsal muscle in fish fed our experimental diets for $17 \mathrm{wks}$ are presented in Table 8 . Hardness, gel strength and chewiness values of fish fed the LO diet were significantly higher than those of fish fed the SLO diet. Fish fed the SLO diet showed significantly higher cohesiveness than fish fed the SO diet. Muscle texture was not affected by dietary lipid sources. Our findings are in accordance with results in a previous study conducted by Regost et al. (2003), who found that organoleptic quality of turbot flesh, particularly odour, colour and texture were significantly affected by dietary lipid sources. However, Montero et al. (2005) reported that replacement of fish oil by linseed, soybean and rapeseed oils did not affect texture and organoleptic properties of European sea bass. The differences are probably due to different levels of inclusion of vegetable oils in the diets, time of interval between slaughter and analyses conducted (Regost et al., 2003), or fish species and cultural seasons (Montero et al., 2005).

The results of this study indicate that fish oil in fish meal based diets for sub-adult olive flounder could be replaced by soybean and linseed oils without negative effects on growth and feed utilization.

\section{ACKNOWLEDGEMENTS}

This work was funded by a grant from the National Fisheries Research and Development Institute (RP-2011AQ-008). 
Table 6. Fatty acid composition (\% of total fatty acids) of the dorsal muscle in sub-adult olive flounder fed experimental diets after 5,11 and 17 wks of feeding

\begin{tabular}{|c|c|c|c|c|c|c|c|c|c|}
\hline & \multicolumn{9}{|c|}{ Diets } \\
\hline & Initial & SLO & $\mathrm{LO}$ & $\mathrm{SO}$ & MIX & LL-HP & HL-SLO & HL-VO & LL-HC \\
\hline Fatty acids & & & 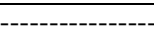 & - & wks - & -------------- & ------------ & -------------- & ------------- \\
\hline C14.0 & 2.0 & $2.0 \pm 0.3$ & $1.9 \pm 0.2$ & $1.9 \pm 0.3$ & $2.2 \pm 0.5$ & $2.1 \pm 0.1$ & $2.1 \pm 0.2$ & $2.0 \pm 0.1$ & $2.0 \pm 0.1$ \\
\hline $\mathrm{C} 16.0$ & 23.3 & $23.9 \pm 1.2$ & $21.3 \pm 0.2$ & $22.4 \pm 0.1$ & $22.0 \pm 0.5$ & $23.0 \pm 0.6$ & $22.2 \pm 0.5$ & $22.2 \pm 0.1$ & $23.0 \pm 0.5$ \\
\hline $\mathrm{C} 16.1$ & 2.1 & $1.9 \pm 0.3$ & $2.0 \pm 0.2$ & $2.0 \pm 0.1$ & $2.1 \pm 0.8$ & $3.1 \pm 0.1$ & $2.4 \pm 0.4$ & $4.1 \pm 1.0$ & $2.7 \pm 0.9$ \\
\hline $\mathrm{C} 18.0$ & 6.5 & $5.5 \pm 0.3$ & $5.7 \pm 0.2$ & $5.4 \pm 0.2$ & $5.6 \pm 0.4$ & $5.2 \pm 0.1$ & $5.0 \pm 0.1$ & $5.1 \pm 0.5$ & $5.6 \pm 0.5$ \\
\hline C18.1n-9 & 13.6 & $10.5 \pm 0.1$ & $12.0 \pm 1.3$ & $12.4 \pm 0.1$ & $10.9 \pm 0.2$ & $10.8 \pm 0.3$ & $10.4 \pm 0.4$ & $12.9 \pm 0.1$ & $10.8 \pm 0.7$ \\
\hline C18.2n-6 & 4.5 & $6.6 \pm 0.5^{\mathrm{a}}$ & $8.7 \pm 0.2^{\mathrm{ab}}$ & $12.4 \pm 0.2^{c}$ & $9.3 \pm 0.8^{b}$ & $6.5 \pm 0.1^{\mathrm{a}}$ & $7.2 \pm 1.7^{\mathrm{ab}}$ & $9.1 \pm 0.1^{\mathrm{b}}$ & $6.5 \pm 0.4^{\mathrm{a}}$ \\
\hline C18.3n-3 & 2.8 & $0.5 \pm 0.3^{\mathrm{a}}$ & $5.6 \pm 0.3^{c}$ & $1.0 \pm 0.1^{\mathrm{ab}}$ & $2.2 \pm 1.0^{\mathrm{b}}$ & $0.5 \pm 0.1^{\mathrm{a}}$ & $0.5 \pm 0.1^{\mathrm{a}}$ & $1.2 \pm 0.1^{\mathrm{ab}}$ & $0.6 \pm 0.1^{\mathrm{a}}$ \\
\hline C20.1n-9 & 0.4 & $0.2 \pm 0.2$ & $0.2 \pm 0.2$ & $0.3 \pm 0.1$ & $0.2 \pm 0.2$ & $0.4 \pm 0.1$ & $0.2 \pm 0.2$ & $0.3 \pm 0.1$ & $0.3 \pm 0.3$ \\
\hline C20.2n-6 & 1.5 & $0.9 \pm 0.9$ & $0.7 \pm 0.7$ & $1.1 \pm 0.1$ & $1.2 \pm 0.1$ & $1.5 \pm 0.3$ & $1.5 \pm 0.1$ & $1.3 \pm 0.1$ & $0.7 \pm 0.7$ \\
\hline C20.4n-6 & 2.4 & $2.1 \pm 0.3$ & $1.6 \pm 0.1$ & $1.6 \pm 0.2$ & $2.0 \pm 0.5$ & $1.8 \pm 0.2$ & $2.3 \pm 0.4$ & $2.0 \pm 0.1$ & $1.7 \pm 0.1$ \\
\hline $\mathrm{C} 20.5 \mathrm{n}-3$ & 6.9 & $6.9 \pm 0.3$ & $5.9 \pm 0.6$ & $5.6 \pm 0.1$ & $5.7 \pm 0.5$ & $7.0 \pm 0.7$ & $6.3 \pm 1.0$ & $5.1 \pm 0.5$ & $7.1 \pm 0.8$ \\
\hline $\mathrm{C} 22.3 n-3$ & 2.1 & $2.4 \pm 2.4$ & $5.0 \pm 0.7$ & $4.2 \pm 0.7$ & $2.7 \pm 0.8$ & $3.3 \pm 0.4$ & $3.1 \pm 0.3$ & $2.7 \pm 0.5$ & $4.0 \pm 1.4$ \\
\hline $\mathrm{C} 22.5 \mathrm{n}-3$ & 3.5 & $3.6 \pm 0.2$ & $3.6 \pm 0.1$ & $3.5 \pm 0.1$ & $3.3 \pm 0.1$ & $3.7 \pm 0.5$ & $3.6 \pm 0.4$ & $3.7 \pm 0.1$ & $3.8 \pm 0.2$ \\
\hline C22.6n-3 & 28.4 & $33.6 \pm 1.6^{\mathrm{b}}$ & $26.2 \pm 0.7^{\mathrm{a}}$ & $26.6 \pm 0.1^{\mathrm{a}}$ & $30.8 \pm 1.8^{\mathrm{b}}$ & $31.5 \pm 1.3^{\mathrm{b}}$ & $33.4 \pm 1.4^{\mathrm{b}}$ & $30.5 \pm 0.5^{\mathrm{b}}$ & $31.6 \pm 1.2^{\mathrm{b}}$ \\
\hline n-3 HUFA & & $46.4 \pm 1.0^{\mathrm{c}}$ & $40.6 \pm 2.0^{\mathrm{ab}}$ & $39.7 \pm 0.6^{\mathrm{a}}$ & $42.5 \pm 2.0^{\mathrm{abc}}$ & $45.3 \pm 0.6^{b c}$ & $46.3 \pm 2.3^{c}$ & $42.0 \pm 0.5^{\mathrm{abc}}$ & $46.4 \pm 2.0^{c}$ \\
\hline$n-3 / n-6$ & & $4.9 \pm 0.1^{\mathrm{bc}}$ & $4.3 \pm 0.6^{\mathrm{abc}}$ & $2.7 \pm 0.1^{\mathrm{a}}$ & $3.6 \pm 0.2^{\mathrm{ab}}$ & $4.8 \pm 0.2^{b c}$ & $4.4 \pm 1.0^{\mathrm{abc}}$ & $3.5 \pm 0.1^{\mathrm{ab}}$ & $5.4 \pm 0.8^{c}$ \\
\hline C14.0 & & $2.3 \pm 0.3$ & $2.0 \pm 0.1$ & $1.8 \pm 0.3$ & $1.8 \pm 0.3$ & $2.6 \pm 0.2$ & $2.1 \pm 0.7$ & $1.3 \pm 0.1$ & $2.9 \pm 0.4$ \\
\hline $\mathrm{C} 16.0$ & & $24.0 \pm 0.2$ & $21.2 \pm 0.7$ & $22.3 \pm 0.4$ & $22.1 \pm 1.6$ & $26.2 \pm 0.6$ & $24.3 \pm 1.5$ & $22.6 \pm 1.8$ & $25.5 \pm 1.8$ \\
\hline C16.1 & & $3.1 \pm 0.6$ & $2.4 \pm 0.1$ & $2.3 \pm 0.3$ & $2.4 \pm 0.3$ & $3.2 \pm 0.2$ & $2.9 \pm 1.0$ & $1.7 \pm 0.3$ & $3.6 \pm 0.7$ \\
\hline C18.0 & & $5.1 \pm 0.2$ & $5.2 \pm 0.2$ & $5.3 \pm 0.1$ & $5.4 \pm 0.3$ & $5.6 \pm 0.1$ & $5.3 \pm 0.3$ & $5.8 \pm 0.1$ & $5.4 \pm 0.2$ \\
\hline C18.1n-9 & & $10.9 \pm 0.4$ & $13.6 \pm 0.5$ & $13.2 \pm 0.8$ & $12.8 \pm 0.6$ & $11.4 \pm 0.3$ & $10.9 \pm 1.4$ & $12.6 \pm 1.1$ & $11.8 \pm 0.9$ \\
\hline $\mathrm{C} 18.2 \mathrm{n}-6$ & & $5.9 \pm 1.3^{\mathrm{a}}$ & $11.7 \pm 0.1^{\mathrm{b}}$ & $21.0 \pm 0.8^{\mathrm{d}}$ & $14.7 \pm 1.2^{\mathrm{c}}$ & $7.5 \pm 0.3^{\mathrm{a}}$ & $5.0 \pm 0.4^{\mathrm{a}}$ & $17.0 \pm 0.9^{\mathrm{c}}$ & $7.7 \pm 1.3^{\mathrm{a}}$ \\
\hline C18.3n-3 & & $2.3 \pm 1.0^{\mathrm{a}}$ & $12.1 \pm 0.1^{\mathrm{c}}$ & $1.8 \pm 0.2^{\mathrm{a}}$ & $5.5 \pm 0.9^{b}$ & $0.7 \pm 0.1^{\mathrm{a}}$ & $0.7 \pm 0.2^{\mathrm{a}}$ & $6.6 \pm 1.0^{\mathrm{b}}$ & $1.3 \pm 0.3^{\mathrm{a}}$ \\
\hline C20.1n-9 & & $1.0 \pm 0.2$ & $0.8 \pm 0.2$ & $0.9 \pm 0.4$ & $0.8 \pm 0.4$ & $0.7 \pm 0.1$ & $0.7 \pm 0.3$ & $0.4 \pm 0.1$ & $0.8 \pm 0.2$ \\
\hline C20.2n-6 & & $0.2 \pm 0.1$ & $0.9 \pm 0.1$ & $0.3 \pm 0.1$ & $1.0 \pm 0.4$ & $0.8 \pm 0.7$ & $1.2 \pm 1.0$ & $0.9 \pm 0.4$ & $0.8 \pm 0.6$ \\
\hline C20.4n-6 & & $2.0 \pm 0.1$ & $1.1 \pm 0.1$ & $1.2 \pm 0.5$ & $0.7 \pm 0.5$ & $0.8 \pm 0.7$ & $1.2 \pm 1.1$ & $0.7 \pm 0.6$ & $0.9 \pm 0.8$ \\
\hline $\mathrm{C} 20.5 \mathrm{n}-3$ & & $8.8 \pm 0.2^{c}$ & $7.2 \pm 0.1^{\mathrm{bc}}$ & $6.8 \pm 0.2^{\mathrm{ab}}$ & $7.1 \pm 0.3^{\mathrm{abc}}$ & $10.9 \pm 0.5^{\mathrm{d}}$ & $8.3 \pm 1.0^{\mathrm{bc}}$ & $5.4 \pm 0.1^{\mathrm{a}}$ & $11.0 \pm 0.9^{\mathrm{d}}$ \\
\hline C22.3n-3 & & $0.6 \pm 0.1$ & $0.5 \pm 0.1$ & $0.4 \pm 0.1$ & $0.4 \pm 0.1$ & $0.5 \pm 0.1$ & $0.4 \pm 0.2$ & $0.3 \pm 0.2$ & $0.5 \pm 0.1$ \\
\hline C22.5n-3 & & $3.1 \pm 0.4^{\mathrm{a}}$ & $3.1 \pm 0.2^{\mathrm{a}}$ & $3.3 \pm 0.1^{\mathrm{ab}}$ & $3.3 \pm 0.2^{\mathrm{ab}}$ & $4.5 \pm 0.3^{c}$ & $2.9 \pm 0.1^{\mathrm{a}}$ & $2.8 \pm 0.1^{\mathrm{a}}$ & $3.9 \pm 0.2^{\mathrm{bc}}$ \\
\hline C22.6n-3 & & $31.1 \pm 1.8^{\mathrm{c}}$ & $18.4 \pm 0.6^{\mathrm{a}}$ & $19.8 \pm 1.5^{\mathrm{ab}}$ & $22.2 \pm 2.4^{\mathrm{ab}}$ & $24.8 \pm 1.1^{\mathrm{b}}$ & $34.7 \pm 3.0^{\mathrm{c}}$ & $22.2 \pm 1.7^{\mathrm{ab}}$ & $24.3 \pm 1.5^{\mathrm{ab}}$ \\
\hline n-3 HUFA & & $43.5 \pm 2.1^{\mathrm{bc}}$ & $29.1 \pm 0.8^{\mathrm{a}}$ & $30.1 \pm 1.4^{\mathrm{a}}$ & $33.0 \pm 2.0^{\mathrm{a}}$ & $40.7 \pm 0.4^{\mathrm{bc}}$ & $46.1 \pm 2.2^{c}$ & $30.6 \pm 1.8^{\mathrm{a}}$ & $39.5 \pm 1.3^{\mathrm{b}}$ \\
\hline$n-3 / n-6$ & & $5.8 \pm 1.2^{\mathrm{c}}$ & $3.0 \pm 0.1^{\mathrm{ab}}$ & $1.4 \pm 0.1^{\mathrm{a}}$ & $2.4 \pm 0.3^{\mathrm{a}}$ & $4.6 \pm 0.1^{\mathrm{bc}}$ & $6.5 \pm 0.7^{\mathrm{c}}$ & $2.1 \pm 0.2^{\mathrm{a}}$ & $4.6 \pm 0.9^{b c}$ \\
\hline $\mathrm{C} 14.0$ & & $1.8 \pm 0.3^{\mathrm{abc}}$ & $1.5 \pm 0.2^{\mathrm{ab}}$ & $1.4 \pm 0.2^{\mathrm{ab}}$ & $1.7 \pm 0.1^{\mathrm{ab}}$ & $2.2 \pm 0.1^{\mathrm{bc}}$ & $1.4 \pm 0.1^{\mathrm{ab}}$ & $1.1 \pm 0.1^{\mathrm{a}}$ & $2.5 \pm 0.5^{\mathrm{c}}$ \\
\hline C16.0 & & $25.6 \pm 0.8$ & $24.4 \pm 1.8$ & $24.5 \pm 0.3$ & $23.4 \pm 0.3$ & $26.0 \pm 0.1$ & $23.0 \pm 1.5$ & $21.8 \pm 0.8$ & $24.2 \pm 1.4$ \\
\hline $\mathrm{C} 16.1$ & & $2.3 \pm 0.3$ & $1.6 \pm 0.1$ & $1.8 \pm 0.2$ & $2.0 \pm 0.1$ & $2.7 \pm 0.1$ & $3.1 \pm 0.8$ & $1.4 \pm 0.1$ & $3.1 \pm 0.6$ \\
\hline C18.0 & & $5.1 \pm 0.4$ & $5.6 \pm 0.4$ & $4.8 \pm 0.1$ & $4.8 \pm 0.1$ & $5.0 \pm 0.1$ & $4.7 \pm 0.1$ & $5.2 \pm 0.1$ & $5.0 \pm 0.3$ \\
\hline C18.1n-9 & & $10.7 \pm 1.0$ & $11.3 \pm 0.1$ & $9.7 \pm 0.6$ & $11.4 \pm 0.6$ & $10.4 \pm 0.6$ & $10.3 \pm 2.0$ & $10.9 \pm 0.5$ & $11.4 \pm 0.7$ \\
\hline C18.2n-6 & & $6.5 \pm 0.3^{b}$ & $10.8 \pm 0.4^{\mathrm{d}}$ & $20.5 \pm 0.4^{\mathrm{g}}$ & $14.8 \pm 0.9^{\mathrm{e}}$ & $6.7 \pm 0.2^{\mathrm{b}}$ & $3.5 \pm 0.4^{\mathrm{a}}$ & $18.5 \pm 0.1^{\mathrm{f}}$ & $8.1 \pm 0.2^{c}$ \\
\hline C18.3n-3 & & $1.4 \pm 0.6^{\mathrm{a}}$ & $9.7 \pm 1.0^{\mathrm{d}}$ & $2.6 \pm 1.0^{\mathrm{a}}$ & $5.4 \pm 0.4^{\mathrm{b}}$ & $1.3 \pm 0.1^{\mathrm{a}}$ & $2.0 \pm 0.4^{\mathrm{a}}$ & $7.8 \pm 0.2^{\mathrm{c}}$ & $1.5 \pm 0.2^{\mathrm{a}}$ \\
\hline C20.1n-9 & & $0.9 \pm 0.2$ & $0.6 \pm 0.1$ & $0.9 \pm 0.2$ & $0.8 \pm 0.1$ & $0.8 \pm 0.1$ & $0.8 \pm 0.1$ & $0.7 \pm 0.1$ & $0.8 \pm 0.1$ \\
\hline C20.2n-6 & & $0.4 \pm 0.2^{\mathrm{ab}}$ & $0.8 \pm 0.1^{\mathrm{c}}$ & $0.3 \pm 0.1^{\mathrm{ab}}$ & $0.5 \pm 0.1^{\mathrm{b}}$ & $0.2 \pm 0.1^{\mathrm{a}}$ & $0.2 \pm 0.1^{\mathrm{a}}$ & $0.5 \pm 0.1^{\mathrm{b}}$ & $0.2 \pm 0.1^{\mathrm{a}}$ \\
\hline C20.4n-6 & & $1.3 \pm 0.4$ & $1.1 \pm 0.2$ & $1.2 \pm 0.3$ & $1.2 \pm 0.1$ & $1.3 \pm 0.1$ & $1.9 \pm 0.1$ & $0.9 \pm 0.1$ & $1.5 \pm 0.1$ \\
\hline C20.5n-3 & & $8.4 \pm 0.8^{\mathrm{c}}$ & $7.2 \pm 0.3^{\mathrm{bc}}$ & $6.4 \pm 0.4^{\mathrm{ab}}$ & $7.4 \pm 0.1^{\mathrm{bc}}$ & $11.3 \pm 0.6^{\mathrm{d}}$ & $8.0 \pm 0.1^{\mathrm{c}}$ & $5.7 \pm 0.3^{\mathrm{a}}$ & $10.3 \pm 0.1^{\mathrm{d}}$ \\
\hline $\mathrm{C} 22.3 \mathrm{n}-3$ & & $0.8 \pm 0.1$ & $0.8 \pm 0.2$ & $0.7 \pm 0.1$ & $0.7 \pm 0.1$ & $0.9 \pm 0.1$ & $0.9 \pm 0.1$ & $0.6 \pm 0.1$ & $0.9 \pm 0.1$ \\
\hline $\mathrm{C} 22.5 \mathrm{n}-3$ & & $3.4 \pm 0.1^{\mathrm{ab}}$ & $3.4 \pm 0.1^{\mathrm{ab}}$ & $3.6 \pm 0.2^{b}$ & $3.3 \pm 0.2^{\mathrm{ab}}$ & $4.8 \pm 0.1^{\mathrm{c}}$ & $3.1 \pm 0.4^{\mathrm{ab}}$ & $2.9 \pm 0.2^{\mathrm{a}}$ & $4.7 \pm 0.1^{\mathrm{c}}$ \\
\hline C22.6n-3 & & $31.7 \pm 0.7^{\mathrm{c}}$ & $21.4 \pm 1.0^{\mathrm{a}}$ & $22.2 \pm 0.7^{\mathrm{a}}$ & $22.9 \pm 1.5^{\mathrm{a}}$ & $26.8 \pm 0.2^{\mathrm{b}}$ & $37.2 \pm 1.7^{\mathrm{d}}$ & $22.4 \pm 0.2^{\mathrm{a}}$ & $26.1 \pm 0.4^{\mathrm{b}}$ \\
\hline n-3 HUFA ${ }^{1}$ & & $44.2 \pm 1.6^{\mathrm{b}}$ & $32.7 \pm 1.1^{\mathrm{a}}$ & $32.7 \pm 1.1^{\mathrm{a}}$ & $34.2 \pm 1.7^{\mathrm{a}}$ & $43.7 \pm 0.7^{\mathrm{b}}$ & $49.2 \pm 1.3^{c}$ & $31.4 \pm 0.6^{\mathrm{a}}$ & $42.0 \pm 0.5^{\mathrm{b}}$ \\
\hline$n-3 / n-6$ & & $5.7 \pm 0.4^{\mathrm{d}}$ & $3.3 \pm 0.1^{\mathrm{b}}$ & $1.6 \pm 0.1^{\mathrm{a}}$ & $2.4 \pm 0.2^{\mathrm{a}}$ & $5.6 \pm 0.3^{\mathrm{d}}$ & $9.4 \pm 0.5^{\mathrm{e}}$ & $2.0 \pm 0.1^{\mathrm{a}}$ & $4.5 \pm 0.1^{\mathrm{c}}$ \\
\hline Crude lipid & & $3.7 \pm 1.0$ & $4.5 \pm 0.3$ & $4.6 \pm 0.3$ & $3.0 \pm 1.7$ & $2.5 \pm 1.0$ & $3.9 \pm 0.7$ & $3.5 \pm 0.6$ & $2.5 \pm 0.5$ \\
\hline
\end{tabular}

Values (mean \pm SE of replications) in the same row not sharing a common superscript are significantly different (p<0.05).

${ }^{1}$ Highly unsaturated fatty acid $(\mathrm{C} \geq 20)$. 


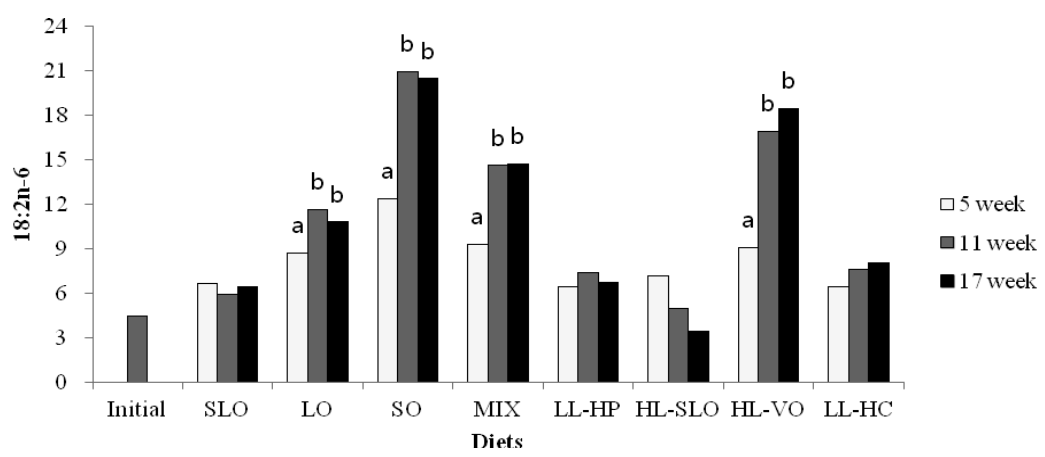

Figure 1. Linoleic acid (18:2n-6) content (\% of total fatty acids) in dorsal muscle of sub-adult olive flounder fed the experimental diets for 5, 11 and 17 wks. The different letter in each diet indicates a significant difference $(\mathrm{p}<0.05)$.

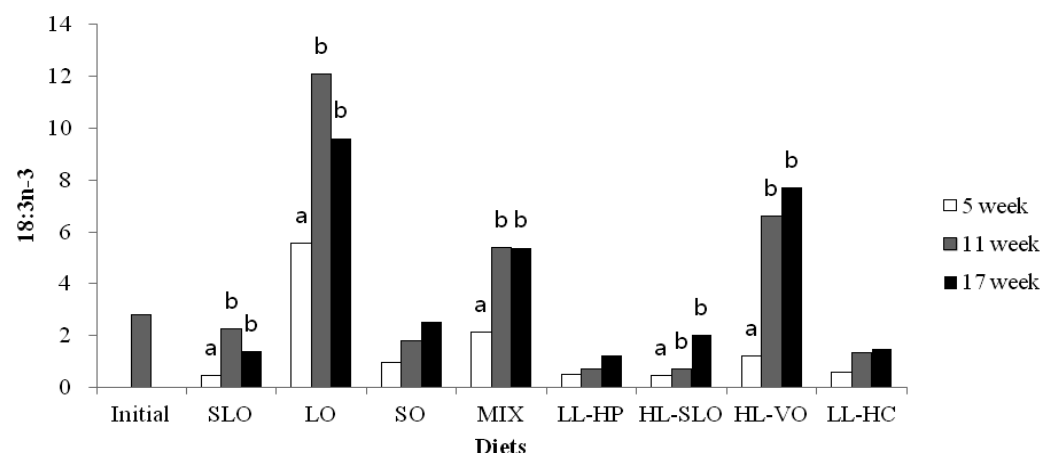

Figure 2. Linolenic acid (18:3n-3) content (\% of total fatty acids) in dorsal muscle of sub-adult olive flounder fed the experimental diets for 5, 11 and 17 wks. The different letter in each diet indicates a significant difference $(\mathrm{p}<0.05)$.

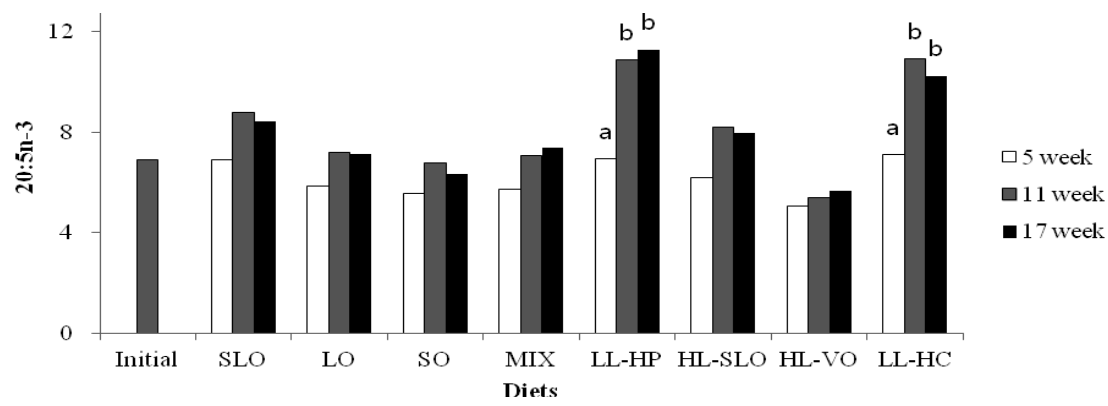

Figure 3. Eicosapentaenoic acid (20:5n-3) content ( $\%$ of total fatty acids) in dorsal muscle of sub-adult olive flounder fed the experimental diets for 5,11 and 17 wks. The different letter in each diet indicates a significant difference $(\mathrm{p}<0.05)$.

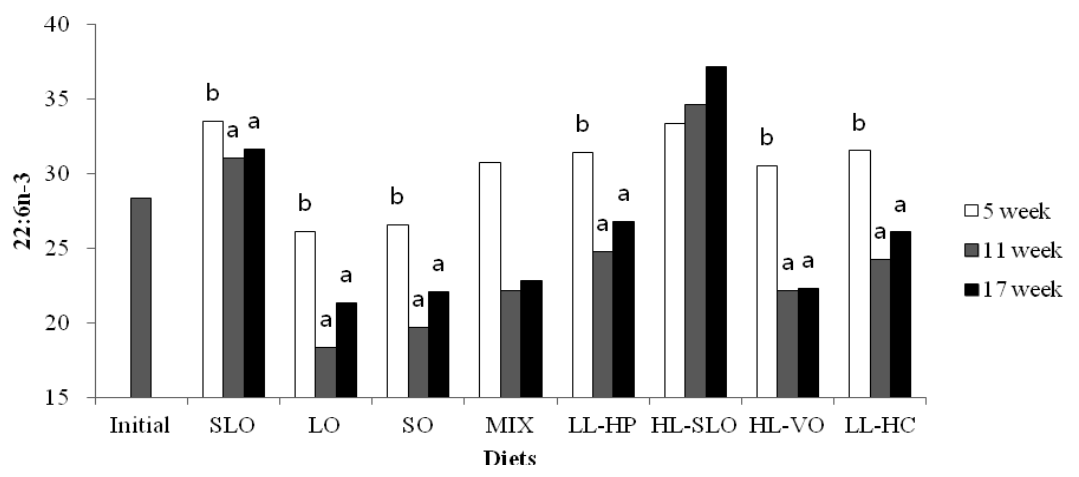

Figure 4. Docosahexaenoic acid (22:6n-3) content ( $\%$ of total fatty acids) in dorsal muscle of sub-adult olive flounder fed the experimental diets for 5, 11 and 17 wks. The different letter in each diet indicates a significant difference $(\mathrm{p}<0.05)$. 
Table 7. Fatty acid composition (\% of total fatty acids) of liver in sub-adult olive flounder fed experimental diet after 5,11 and 17 wks of feeding

\begin{tabular}{|c|c|c|c|c|c|c|c|c|c|}
\hline & \multicolumn{9}{|c|}{ Diets } \\
\hline & Initial & SLO & $\mathrm{LO}$ & $\mathrm{SO}$ & MIX & LL-HP & HL-SLO & HL-VO & LL-HC \\
\hline Fatty acids & & ----------- & -------------' & 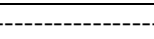 & $5 \mathrm{wk}$ & 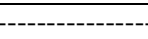 & -------------. & 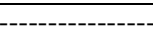 & -------------- \\
\hline C14.0 & & $3.0 \pm 0.6$ & $2.8 \pm 0.3$ & $3.0 \pm 0.2$ & $2.7 \pm 0.2$ & $3.7 \pm 0.4$ & $3.2 \pm 0.2$ & $2.7 \pm 0.2$ & $3.6 \pm 0.1$ \\
\hline C16.0 & & $20.3 \pm 1.6$ & $17.4 \pm 0.7$ & $19.3 \pm 1.7$ & $19.0 \pm 0.7$ & $21.9 \pm 1.5$ & $19.9 \pm 1.6$ & $17.0 \pm 0.5$ & $20.6 \pm 0.1$ \\
\hline C16.1 & & $6.3 \pm 1.3$ & $5.4 \pm 1.0$ & $5.5 \pm 0.5$ & $5.0 \pm 0.5$ & $6.8 \pm 0.6$ & $5.6 \pm 0.4$ & $4.6 \pm 0.3$ & $6.8 \pm 0.3$ \\
\hline C18.0 & & $4.0 \pm 0.4$ & $4.8 \pm 1.0$ & $4.5 \pm 0.3$ & $4.5 \pm 0.2$ & $4.6 \pm 0.6$ & $4.2 \pm 0.2$ & $4.2 \pm 0.2$ & $4.8 \pm 0.1$ \\
\hline C18.1n-9 & & $25.4 \pm 0.1^{\mathrm{ab}}$ & $26.9 \pm 0.1^{\mathrm{b}}$ & $26.2 \pm 0.5^{\mathrm{b}}$ & $26.0 \pm 0.3^{\mathrm{b}}$ & $30.0 \pm 0.6^{c}$ & $22.5 \pm 2.4^{\mathrm{a}}$ & $26.5 \pm 0.7^{\mathrm{b}}$ & $26.6 \pm 0.3^{\mathrm{b}}$ \\
\hline C $18.2 n-6$ & & $9.0 \pm 1.5^{\mathrm{ab}}$ & $11.1 \pm 0.5^{\mathrm{b}}$ & $18.2 \pm 1.0^{\mathrm{d}}$ & $15.3 \pm 0.3^{c}$ & $7.8 \pm 0.1^{\mathrm{a}}$ & $7.7 \pm 0.6^{\mathrm{a}}$ & $16.5 \pm 1.1^{\mathrm{cd}}$ & $8.0 \pm 0.6^{\mathrm{a}}$ \\
\hline C18.3n-3 & & $1.7 \pm 0.9^{\mathrm{a}}$ & $9.3 \pm 0.7^{\mathrm{c}}$ & $1.7 \pm 0.2^{\mathrm{a}}$ & $4.9 \pm 0.3^{\mathrm{b}}$ & $0.9 \pm 0.2^{\mathrm{a}}$ & $0.9 \pm 0.1^{\mathrm{a}}$ & $5.9 \pm 0.3^{\mathrm{b}}$ & $0.9 \pm 0.1^{\mathrm{a}}$ \\
\hline C20.1n-9 & & $2.1 \pm 0.5^{\mathrm{ab}}$ & $1.8 \pm 0.1^{\mathrm{a}}$ & $2.2 \pm 0.1^{\mathrm{ab}}$ & $2.5 \pm 0.4^{\mathrm{abc}}$ & $3.1 \pm 0.1^{\mathrm{c}}$ & $3.9 \pm 0.1^{\mathrm{d}}$ & $2.2 \pm 0.1^{\mathrm{ab}}$ & $2.7 \pm 0.1^{\mathrm{bc}}$ \\
\hline C20.2n-6 & & $0.8 \pm 0.1$ & $1.2 \pm 0.2$ & $0.6 \pm 0.2$ & $0.8 \pm 0.1$ & $1.2 \pm 0.7$ & $1.0 \pm 0.3$ & $1.1 \pm 0.4$ & $0.8 \pm 0.2$ \\
\hline C20.4n-6 & & $1.7 \pm 0.1^{\mathrm{a}}$ & $3.1 \pm 0.1^{\mathrm{c}}$ & $1.6 \pm 0.3^{\mathrm{a}}$ & $2.3 \pm 0.2^{\mathrm{b}}$ & $1.7 \pm 0.2^{\mathrm{a}}$ & $2.2 \pm 0.2^{\mathrm{b}}$ & $2.4 \pm 0.1^{\mathrm{b}}$ & $1.6 \pm 0.1^{\mathrm{a}}$ \\
\hline$C 20.5 n-3$ & & $5.4 \pm 0.4^{b}$ & $4.7 \pm 0.1^{\mathrm{ab}}$ & $5.2 \pm 0.1^{\mathrm{ab}}$ & $5.1 \pm 0.1^{\mathrm{ab}}$ & $5.3 \pm 0.1^{\mathrm{ab}}$ & $6.9 \pm 0.1^{c}$ & $4.3 \pm 0.1^{\mathrm{a}}$ & $6.5 \pm 0.8^{c}$ \\
\hline C22.3n-3 & & $1.1 \pm 0.1$ & $1.0 \pm 0.1$ & $0.9 \pm 0.2$ & $1.0 \pm 0.3$ & $1.1 \pm 0.1$ & $1.4 \pm 0.1$ & $0.9 \pm 0.1$ & $1.2 \pm 0.1$ \\
\hline$C 22.5 n-3$ & & $4.3 \pm 0.9$ & $3.4 \pm 0.1$ & $3.8 \pm 0.2$ & $3.5 \pm 0.3$ & $4.1 \pm 1.1$ & $4.5 \pm 0.5$ & $3.5 \pm 0.4$ & $5.1 \pm 0.6$ \\
\hline C22.6n-3 & & $15.3 \pm 0.1^{\mathrm{c}}$ & $7.4 \pm 0.8^{\mathrm{a}}$ & $7.8 \pm 0.1^{\mathrm{a}}$ & $7.9 \pm 0.2^{\mathrm{a}}$ & $8.1 \pm 0.4^{\mathrm{a}}$ & $16.4 \pm 0.5^{\mathrm{c}}$ & $8.7 \pm 0.3^{\mathrm{a}}$ & $11.2 \pm 0.6^{\mathrm{b}}$ \\
\hline n-3 HUFA & & $26.1 \pm 1.3^{\mathrm{b}}$ & $16.5 \pm 1.0^{\mathrm{a}}$ & $17.6 \pm 0.1^{\mathrm{a}}$ & $17.4 \pm 0.3^{\mathrm{a}}$ & $18.6 \pm 1.5^{\mathrm{a}}$ & $29.1 \pm 0.1^{\mathrm{c}}$ & $17.2 \pm 0.6^{\mathrm{a}}$ & $23.9 \pm 0.7^{b}$ \\
\hline$n-3 / n-6$ & & $2.5 \pm 0.5^{\mathrm{cd}}$ & $1.7 \pm 0.1^{\mathrm{abc}}$ & $1.0 \pm 0.1^{\mathrm{a}}$ & $1.3 \pm 0.1^{\mathrm{ab}}$ & $1.9 \pm 0.3^{\mathrm{bc}}$ & $2.8 \pm 0.3^{\mathrm{d}}$ & $1.2 \pm 0.1^{\mathrm{ab}}$ & $2.5 \pm 0.2^{\mathrm{cd}}$ \\
\hline C14.0 & & $3.8 \pm 0.1$ & $3.4 \pm 0.2$ & $3.4 \pm 0.2$ & $4.0 \pm 0.1$ & $4.1 \pm 0.1$ & $4.1 \pm 0.1$ & $3.4 \pm 0.1$ & $4.1 \pm 0.2$ \\
\hline $\mathrm{C} 16.0$ & & $21.7 \pm 1.2^{\mathrm{bc}}$ & $20.4 \pm 0.1^{\mathrm{b}}$ & $19.4 \pm 1.0^{\mathrm{b}}$ & $21.2 \pm 1.3^{b c}$ & $23.8 \pm 0.5^{\mathrm{c}}$ & $20.3 \pm 0.6^{\mathrm{b}}$ & $15.5 \pm 0.1^{\mathrm{a}}$ & $21.9 \pm 0.2^{\mathrm{bc}}$ \\
\hline C16.1 & & $7.7 \pm 0.6^{\mathrm{b}}$ & $6.3 \pm 0.5^{\mathrm{b}}$ & $4.7 \pm 0.5^{\mathrm{a}}$ & $6.8 \pm 0.5^{\mathrm{b}}$ & $8.9 \pm 0.1^{\mathrm{c}}$ & $7.4 \pm 0.3^{\mathrm{b}}$ & $4.5 \pm 0.1^{\mathrm{a}}$ & $11.6 \pm 0.4^{\mathrm{d}}$ \\
\hline C18.0 & & $3.9 \pm 0.5$ & $3.6 \pm 0.1$ & $4.0 \pm 0.2$ & $4.4 \pm 0.1$ & $4.7 \pm 0.1$ & $4.6 \pm 0.3$ & $4.0 \pm 0.4$ & $4.4 \pm 0.8$ \\
\hline C18.1n-9 & & $25.7 \pm 0.1^{\mathrm{ab}}$ & $24.2 \pm 1.1^{\mathrm{a}}$ & $25.1 \pm 0.4^{\mathrm{ab}}$ & $25.8 \pm 0.2^{\mathrm{ab}}$ & $28.5 \pm 0.6^{\mathrm{c}}$ & $24.1 \pm 0.7^{\mathrm{a}}$ & $24.4 \pm 0.1^{\mathrm{a}}$ & $27.2 \pm 0.6^{\mathrm{b}}$ \\
\hline C18.2n-6 & & $5.9 \pm 0.2^{\mathrm{a}}$ & $10.8 \pm 0.3^{b}$ & $23.7 \pm 0.3^{\mathrm{e}}$ & $15.5 \pm 1.5^{\mathrm{c}}$ & $6.6 \pm 0.6^{\mathrm{a}}$ & $4.5 \pm 0.2^{\mathrm{a}}$ & $19.1 \pm 0.4^{\mathrm{d}}$ & $6.9 \pm 1.0^{\mathrm{a}}$ \\
\hline C18.3n-3 & & $0.6 \pm 0.1^{\mathrm{a}}$ & $10.7 \pm 0.4^{\mathrm{c}}$ & $2.6 \pm 0.8^{b}$ & $3.6 \pm 1.2^{\mathrm{b}}$ & $0.6 \pm 0.2^{\mathrm{a}}$ & $0.6 \pm 0.1^{\mathrm{a}}$ & $10.0 \pm 0.1^{\mathrm{c}}$ & $0.5 \pm 0.1^{\mathrm{a}}$ \\
\hline C20.1n-9 & & $1.5 \pm 0.1$ & $1.3 \pm 0.2$ & $1.0 \pm 0.5$ & $1.7 \pm 0.1$ & $1.5 \pm 0.1$ & $1.5 \pm 0.1$ & $0.9 \pm 0.1$ & $1.5 \pm 0.1$ \\
\hline$C 20.2 n-6$ & & $3.7 \pm 0.1^{\mathrm{cd}}$ & $2.3 \pm 0.7^{\mathrm{ab}}$ & $1.9 \pm 0.1^{\mathrm{ab}}$ & $2.2 \pm 0.3^{\mathrm{ab}}$ & $2.9 \pm 0.2^{\mathrm{bc}}$ & $4.4 \pm 0.3^{\mathrm{d}}$ & $1.7 \pm 0.1^{\mathrm{a}}$ & $2.3 \pm 0.2^{\mathrm{ab}}$ \\
\hline C20.4n-6 & & $1.5 \pm 0.1^{\mathrm{ab}}$ & $3.2 \pm 0.2^{\mathrm{c}}$ & $2.0 \pm 1.0^{\mathrm{abc}}$ & $1.6 \pm 0.5^{\mathrm{ab}}$ & $1.8 \pm 0.1^{\mathrm{a}}$ & $1.6 \pm 0.1^{\mathrm{ab}}$ & $2.7 \pm 0.1^{\mathrm{bc}}$ & $0.7 \pm 0.1^{\mathrm{a}}$ \\
\hline C20.5n-3 & & $6.8 \pm 0.2^{\mathrm{bc}}$ & $5.7 \pm 1.3^{\mathrm{ab}}$ & $4.3 \pm 0.3^{\mathrm{a}}$ & $4.5 \pm 0.2^{\mathrm{a}}$ & $5.8 \pm 0.1^{\mathrm{ab}}$ & $8.1 \pm 0.1^{\mathrm{c}}$ & $4.7 \pm 0.2^{\mathrm{a}}$ & $5.3 \pm 0.3^{\mathrm{ab}}$ \\
\hline C22.3n-3 & & $0.5 \pm 0.1^{\mathrm{ab}}$ & $0.2 \pm 0.2^{\mathrm{a}}$ & $0.4 \pm 0.1^{\mathrm{ab}}$ & $0.4 \pm 0.1^{\mathrm{ab}}$ & $0.5 \pm 0.1^{\mathrm{ab}}$ & $0.9 \pm 0.4^{b}$ & $0.5 \pm 0.1^{\mathrm{ab}}$ & $1.4 \pm 0.1^{\mathrm{c}}$ \\
\hline C22.5n-3 & & $5.0 \pm 0.8^{\mathrm{bc}}$ & $3.6 \pm 0.2^{\mathrm{ab}}$ & $3.7 \pm 0.4^{\mathrm{ab}}$ & $3.8 \pm 0.4^{\mathrm{ab}}$ & $5.5 \pm 0.2^{\mathrm{c}}$ & $5.7 \pm 0.2^{\mathrm{c}}$ & $3.2 \pm 0.1^{\mathrm{a}}$ & $5.9 \pm 0.9^{c}$ \\
\hline C22.6n-3 & & $11.7 \pm 0.3^{\mathrm{d}}$ & $4.4 \pm 0.3^{\mathrm{ab}}$ & $3.8 \pm 0.2^{\mathrm{a}}$ & $4.4 \pm 0.5^{\mathrm{ab}}$ & $5.0 \pm 0.3^{\mathrm{abc}}$ & $12.3 \pm 0.8^{\mathrm{d}}$ & $5.5 \pm 0.4^{\mathrm{bc}}$ & $6.3 \pm 0.4^{\mathrm{c}}$ \\
\hline n-3 HUFA & & $24.0 \pm 0.9^{\mathrm{d}}$ & $13.9 \pm 1.2^{\mathrm{ab}}$ & $12.2 \pm 0.8^{\mathrm{a}}$ & $13.2 \pm 1.3^{\mathrm{a}}$ & $16.7 \pm 0.3^{b c}$ & $27.0 \pm 0.7^{\mathrm{e}}$ & $13.8 \pm 0.7^{\mathrm{ab}}$ & $19.0 \pm 1.0^{\mathrm{c}}$ \\
\hline$n-3 / n-6$ & & $2.2 \pm 0.1^{\mathrm{f}}$ & $1.5 \pm 0.1^{\mathrm{c}}$ & $0.5 \pm 0.1^{\mathrm{a}}$ & $0.9 \pm 0.1^{\mathrm{b}}$ & $1.7 \pm 0.1^{\mathrm{d}}$ & $2.6 \pm 0.1^{\mathrm{g}}$ & $0.9 \pm 0.1^{\mathrm{b}}$ & $2.0 \pm 0.1^{\mathrm{e}}$ \\
\hline C14.0 & & $3.1 \pm 0.4$ & $3.1 \pm 0.4$ & $3.1 \pm 0.3$ & $\begin{array}{l}3.3 \pm 0.3 \\
\text { wk }\end{array}$ & $3.4 \pm 0.6$ & $3.6 \pm 0.3$ & $3.2 \pm 0.1$ & $3.9 \pm 0.1$ \\
\hline C16.0 & & $21.2 \pm 0.5^{\mathrm{d}}$ & $16.8 \pm 0.2^{\mathrm{b}}$ & $17.0 \pm 0.1^{\mathrm{b}}$ & $17.6 \pm 0.1^{\mathrm{b}}$ & $22.2 \pm 0.6^{\mathrm{e}}$ & $19.5 \pm 0.3^{\mathrm{c}}$ & $13.7 \pm 0.3^{\mathrm{a}}$ & $20.6 \pm 0.3^{d}$ \\
\hline C16.1 & & $6.3 \pm 1.2^{\mathrm{abc}}$ & $5.0 \pm 0.1^{\mathrm{a}}$ & $5.3 \pm 1.1^{\mathrm{ab}}$ & $5.0 \pm 0.8^{\mathrm{a}}$ & $8.4 \pm 0.1^{\mathrm{c}}$ & $8.0 \pm 0.7^{\mathrm{bc}}$ & $4.3 \pm 0.1^{\mathrm{a}}$ & $8.2 \pm 1.2^{\mathrm{bc}}$ \\
\hline C18.0 & & $5.4 \pm 0.9$ & $5.3 \pm 0.2$ & $4.5 \pm 1.0$ & $4.6 \pm 0.7$ & $5.1 \pm 0.5$ & $4.5 \pm 0.6$ & $4.2 \pm 0.1$ & $5.1 \pm 0.3$ \\
\hline C18.1n-9 & & $24.7 \pm 0.6^{\mathrm{bc}}$ & $20.7 \pm 1.7^{\mathrm{ab}}$ & $20.8 \pm 1.6^{\mathrm{ab}}$ & $20.7 \pm 0.8^{\mathrm{a}}$ & $25.7 \pm 0.1^{\mathrm{c}}$ & $20.9 \pm 1.4^{\mathrm{ab}}$ & $21.2 \pm 0.4^{\mathrm{ab}}$ & $24.7 \pm 1.2^{\mathrm{bc}}$ \\
\hline C18.2n-6 & & $5.4 \pm 0.2^{\mathrm{b}}$ & $11.9 \pm 0.4^{\mathrm{c}}$ & $23.2 \pm 0.6^{\mathrm{e}}$ & $15.9 \pm 0.4^{\mathrm{d}}$ & $6.3 \pm 0.1^{\mathrm{b}}$ & $3.7 \pm 0.2^{\mathrm{a}}$ & $21.9 \pm 0.2^{\mathrm{e}}$ & $6.6 \pm 1.1^{\mathrm{b}}$ \\
\hline C18.3n-3 & & $1.2 \pm 0.1^{\mathrm{a}}$ & $11.8 \pm 1.0^{\mathrm{d}}$ & $2.7 \pm 0.2^{\mathrm{b}}$ & $5.8 \pm 0.1^{\mathrm{c}}$ & $0.1 \pm 0.1^{\mathrm{a}}$ & $0.3 \pm 0.3^{\mathrm{a}}$ & $10.8 \pm 0.4^{\mathrm{d}}$ & $0.5 \pm 0.5^{\mathrm{a}}$ \\
\hline C20.1n-9 & & $2.7 \pm 1.1^{\mathrm{abc}}$ & $1.3 \pm 0.4^{\mathrm{a}}$ & $2.2 \pm 0.7^{\mathrm{ab}}$ & $1.6 \pm 0.1^{\mathrm{ab}}$ & $4.3 \pm 0.2^{\mathrm{bc}}$ & $4.3 \pm 0.6^{c}$ & $1.1 \pm 0.1^{\mathrm{a}}$ & $3.6 \pm 0.6^{b c}$ \\
\hline C20.2n-6 & & $0.4 \pm 0.4$ & $1.1 \pm 0.1$ & $0.7 \pm 0.1$ & $0.7 \pm 0.1$ & $0.1 \pm 0.1$ & $0.4 \pm 0.4$ & $1.0 \pm 0.1$ & $0.3 \pm 0.3$ \\
\hline C20.4n-6 & & $1.8 \pm 0.2^{\mathrm{abc}}$ & $3.5 \pm 0.2^{\mathrm{d}}$ & $1.7 \pm 0.3^{\mathrm{abc}}$ & $2.6 \pm 0.1^{\mathrm{bcd}}$ & $0.8 \pm 0.8^{\mathrm{a}}$ & $2.8 \pm 0.2^{\mathrm{cd}}$ & $2.6 \pm 0.1^{\text {bcd }}$ & $1.6 \pm 0.1^{\mathrm{ab}}$ \\
\hline C20.5n-3 & & $8.2 \pm 1.2$ & $6.7 \pm 1.0$ & $6.3 \pm 0.1$ & $6.7 \pm 0.2$ & $6.7 \pm 0.7$ & $7.6 \pm 0.6$ & $6.0 \pm 0.2$ & $6.2 \pm 0.8$ \\
\hline C22.3n-3 & & $1.1 \pm 0.1$ & $0.4 \pm 0.4$ & $0.5 \pm 0.1$ & $0.9 \pm 0.3$ & $0.6 \pm 0.6$ & $0.6 \pm 0.6$ & $0.3 \pm 0.3$ & $0.6 \pm 0.6$ \\
\hline$C 22.5 n-3$ & & $4.5 \pm 0.2^{\mathrm{cd}}$ & $3.4 \pm 0.1^{\mathrm{ab}}$ & $4.1 \pm 0.5^{\mathrm{bc}}$ & $4.1 \pm 0.2^{\mathrm{bc}}$ & $5.1 \pm 0.3^{\mathrm{d}}$ & $4.8 \pm 0.1^{\mathrm{cd}}$ & $2.9 \pm 0.3^{\mathrm{a}}$ & $4.9 \pm 0.3^{\mathrm{cd}}$ \\
\hline C22.6n-3 & & $14.3 \pm 0.6^{\mathrm{c}}$ & $7.5 \pm 0.5^{\mathrm{a}}$ & $8.1 \pm 0.4^{\mathrm{a}}$ & $10.8 \pm 0.3^{\mathrm{b}}$ & $11.5 \pm 0.2^{b}$ & $19.3 \pm 0.9^{\mathrm{d}}$ & $7.4 \pm 0.3^{\mathrm{a}}$ & $13.5 \pm 0.1^{\mathrm{c}}$ \\
\hline n-3 HUFA ${ }^{1}$ & & $28.1 \pm 0.4^{\mathrm{c}}$ & $18.0 \pm 1.0^{\mathrm{a}}$ & $19.0 \pm 0.8^{\mathrm{a}}$ & $22.5 \pm 0.6^{\mathrm{b}}$ & $23.9 \pm 0.2^{\mathrm{b}}$ & $32.3 \pm 2.2^{\mathrm{d}}$ & $16.4 \pm 0.6^{\mathrm{a}}$ & $25.0 \pm 0.9^{\mathrm{bc}}$ \\
\hline$n-3 / n-6$ & & $3.9 \pm 0.2^{\mathrm{e}}$ & $1.8 \pm 0.1^{\mathrm{c}}$ & $0.9 \pm 0.1^{\mathrm{a}}$ & $1.5 \pm 0.1^{\mathrm{bc}}$ & $3.4 \pm 0.3^{\mathrm{de}}$ & $4.8 \pm 0.2^{f}$ & $1.1 \pm 0.1^{\mathrm{ab}}$ & $3.1 \pm 0.4^{\mathrm{d}}$ \\
\hline
\end{tabular}

Values (mean \pm SE of replications) in the same column not sharing a common superscript are significantly different (p<0.05).

${ }^{1}$ Highly unsaturated fatty acid $(\mathrm{C} \geq 20)$. 
Table 8. Physical properties of the dorsal muscle in sub-adult olive flounder fed the experimental diets for 17 wks

\begin{tabular}{lcccc}
\hline & \multicolumn{3}{c}{ Diets } \\
\cline { 2 - 5 } & SLO & LO & SO & $2,349 \pm 207^{\mathrm{ab}}$ \\
\hline Hardness $\left(\mathrm{g} / \mathrm{cm}^{2}\right)$ & $2,157 \pm 252^{\mathrm{a}}$ & $2,684 \pm 147^{\mathrm{b}}$ & $2,568 \pm 71^{\mathrm{ab}}$ & $1,845 \pm 206^{\mathrm{a}}$ \\
Gel strength $\left(\mathrm{g} / \mathrm{cm}^{2}\right)$ & $1,654 \pm 189^{\mathrm{a}}$ & $2,120 \pm 108^{\mathrm{b}}$ & $2,020 \pm 78^{\mathrm{ab}}$ & $77 \pm 3.8$ \\
Texture (\%) & $72 \pm 0.0$ & $72 \pm 0.9$ & $75 \pm 2.1$ & $35.0 \pm 5.7^{\mathrm{ab}}$ \\
Cohesiveness (\%) & $40.9 \pm 3.7^{\mathrm{b}}$ & $37.9 \pm 1.7^{\mathrm{ab}}$ & $29.0 \pm 2.6^{\mathrm{a}}$ & $475 \pm 24.2^{\mathrm{a}}$ \\
Chewiness (g) & $498 \pm 11.2^{\mathrm{a}}$ & $596 \pm 6.8^{\mathrm{b}}$ & $439 \pm 19.7^{\mathrm{a}}$ & $32.9 \pm 0.5^{\mathrm{a}}$ \\
Breaking strength $(\mathrm{kg})$ & $36.2 \pm 0.9^{\mathrm{ab}}$ & $42.8 \pm 0.9^{\mathrm{b}}$ & $36.4 \pm 0.1^{\mathrm{ab}}$ \\
\hline
\end{tabular}

Values (mean \pm SE of replications) in the same column not sharing a common superscript are significantly different ( $<<0.05$ ).

\section{REFERENCES}

Abimorad, E. G. and D. J. Carneiro. 2007. Digestibility and performance of pacu (Piaractus mesopotamicus) juveniles-fed diets containing different protein, lipid and carbohydrate levels. Aquac. Nutr. 13:1-9.

AOAC (Association of Official Analytical Chemists). 1995. Official methods of analysis. 16th edn. Association of Official Analytical Chemists, Arlington, Virginia, USA.

Bell, J. G., J. McEvoy, D. R. Tocher, F. McGhee, P. J. Campbell and J. P. Sargent. 2001. Replacement of fish oil with rapeseed oil in diets of Atlantic salmon (Salmo salar) affects tissue lipid composition and hepatocyte fatty acid metabolism. J. Nutr. 131:1535-1543.

Bell, J. G., R. J. Henderson, D. R. Tocher and J. R. Sargent. 2004. Replacement of dietary fish oil with increasing levels of linseed oil: modification of flesh fatty acid compositions in Atlantic salmon (Salmo salar) using a fish oil finishing diet. Lipids 39:223-232.

Caballero, M. J., A. Obach, G. Roselund, D. Montero, M. Gisvold and M. S. Izquierdo. 2002. Impact of different dietary lipid sources on growth, lipid digestibility, tissue fatty acid composition and histology of rainbow trout, Oncorhynchus mykiss. Aquaculture 214:253-271.

Dannevig, B. H. and K. R. Norum. 1982. Cholesterol esterification and lipids in blood plasma of the char (Salmo alpinus L.) during sexual maturation. Comp. Biochem. Physiol B. 73:771777.

Deng, J., K. Mai, Q. Ai, W. Zhang, X. Wang, W. Xu and Z. Liufu. 2006. Effects of replacing fish meal with soy protein concentrate on feed intake and growth of juvenile Japanese flounder, Paralichthys olivaceus. Aquaculture 258:503-513.

Duncan, D. B. 1955. Multiple-range and multiple $F$ tests. Biometrics 11:1-42.

Este'vez, A., A. Delgado, P. Hortelano and M. Alejandre. 1996. Characterization of mevalonate metabolism in the sea bass, Dicentrarchus labrax L, liver. Fish Physiol. Biochem. 15:205211.

Francis, D. S., G. M. Turchini, P. L. Jones and S. S. De Silva. 2007. Effects of fish oil substitution with a mix blend vegetable oil on nutrient digestibility in Murray cod, Maccullochella peelii peelii. Aquaculture 269:447-455.

Folch, J., M. Lees and G. H. Sloane-Stanley. 1957. A simple method for the isolation and purification of total lipids from animal tissues. J. Biol. Chem. 226:497-509.
Fountoulaki, E., A. Vasilaki, R. Hurtado, K. Grigorakis, I. Karacostas, I. Nengas, G. Rigos, Y. Kotzamanis, B. Venou and M. N. Alexis. 2009. Fish oil substitution by vegetables oils in commercial diets for gilthead sea bream (Sparus aurata L.); effects on growth performance, flesh quality, and fillet fatty acid profile; recovery of fatty acid profiles by a fish oil finishing diet under fluctuating water temperatures. Aquaculture 289:317-326.

Gilman, C. I., F. D. L., Leusch, W. C. Breckenridge and D. L. MacLathcy. 2003. Effects of a phytosterol mixture on male fish plasma lipoprotein fractions and testis P450scc activity. Gen. Comp. Endocrinol. 130:172-184.

Glencross, B. D., W. E. Hawkins and J. G. Curnow. 2003. Evaluation of canola oils as alternative lipid resources in diets for juvenile red seabream, Pagrus auratus. Aquac. Nutr. 9: 305-315.

Hillestad, M. And F. T. Johnsen. 1994. High-energy/low-protein diets for Atlantic salmon: effects on growth, nutrient retention and slaughter quality. Aquaculture 124:109-116.

Herzberg, G. R., S. R. T. Craig and R. Levy. 1996. Eicosapentaenoic acid is oxidized more rapidly than docosahexanenoic acid by muscle and liver. Nutr. Res. 16: 639-644.

Izquierdo, M. S., D. Montero, L. Robaina, M. J. Caballero, G. Rosenlund and R. Gines. 2005. Alterations in fillet fatty acid profile and flesh quality in gilthead seabream (Sparus aurata) fed vegetable oils for a long term period. Recovery of fatty acid profiles by fish oil feeding. Aquaculture 250:431-444.

Kaushik, S. J. and C. B. Cowey. 1991. Dietary factors affecting nitrogen excretion by fish. In: Nutritional Strategies and Aquaculture Waste (Ed. C. B. Cowey and C. Y. Cho). University of Guelph, Canada, pp. 3-19.

Kim, K. D. and S. M. Lee. 2004. Requirement of dietary n-3 highly unsaturated fatty acids for juvenile flounder (Paralichthys olivaceus). Aquaculture 229:315-323.

Kim, K. D., S. M. Lee, H. G. Park, S. C. Bai and Y. H. Lee. 2002. Essentiality of dietary n-3 highly unsaturated fatty acids in juvenile Japanese flounder (Paralichthys olivaceus). J. World Aquac. Soc. 33:432-440.

Kim, K. D., Y. J. Kang, H. Y. Lee, K. W. Kim, K. M. Kim and S. M. Lee. 2006. Evaluation of extruded pellets as a grower diet for grower flounder Paralichthys olivaceus. J. Aquac. 19:173177.

Lee, S. M., S. H. Cho and K. D. Kim. 2000. Effects of dietary protein and energy levels on growth and body composition of 
juvenile flounder (Paralichthys olivaceus). J. World Aquac. Soc. 31:306-315.

Lin, Y. H. and S. Y. Shiau. 2007. Effects of dietary blend of fish oil with corn oil on growth and non-specific immune responses of grouper, Epinephelus malabaricus. Aquac. Nutr. 13:137-144.

Menoyo, D., M. S. Izquierdo, L. Robaina, R. Ginés, C. J. LopezBote and J. M. Bautista. 2004. Adaptation of lipid metabolism, tissue composition and flesh quality in gilthead sea bream (Sparus aurata) to the replacement of dietary fish oil by linseed and soybean oils. Br. J. Nutr. 92:41-52.

Montero, D., L. Robaina, M. J. Caballero, R. Gine's and M. S. Izquierdo. 2005. Growth, feed utilization and flesh quality of European sea bass (Dicentrarchus labrax) fed diets containing vegetable oils: a time-course study on the effect of re-feeding period with a $100 \%$ fish oil diet. Aquaculture 248:121-134.

Mourente, G. and J. G. Bell. 2006. Partial replacement of dietary fish oil with blends of vegetable oils (rapeseed, linseed and palm oils) in diets for European sea bass (Dicentrarchus labrax L.) over a long term growth study: Effects on muscle and liver fatty acid composition and effectiveness of a fish oil finishing diet. Comp. Biochem. Physiol. B Biochem. Mol. Biol. 145:389-399.

Peng, S., C. Liqiao, G. Q. Jian, H. Junli, Y. Na, L. Zhangqiang, Y. Jinyun and S. Xinjin. 2008. Effects of replacement of dietary fish oil by soybean oil on growth performance and liver biochemical composition in juvenile black seabream, Acanthopagrus schlegeli. Aquaculture 276:154-161.

Peres, H. and A. Oliva-Teles. 1999. Effect of the dietary lipid level on growth performance and feed utilisation by European sea bass juveniles (Dicentrarchus labrax). Aquaculture 179:325334
Piedecausa, M. A., M. J. Mazón, B. G. García and M. D. Hernández. 2007. Effects of total replacement of fish oil by vegetable oils in the diets of sharpsnout seabream (Diplodus puntazzo). Aquaculture 263:211-219.

Pimentel-Rodrigues, A. and A. Oliva-Teles. 2007. Phosphorus availability of inorganic phosphates and fish meals in European sea bass (Dicentrarchus labrax L.) juveniles. Aquaculture 267:300-307.

Regost, C., J. Arzel, J. Robin, G. Roselund and S. J. Kaushik. 2003 Total replacement of fish oil by soybean or oil with return to fish oil in turbot (Psetta maxima) 1. Growth performance, flesh fatty acid profile, and lipid metabolism. Aquaculture 217: 465-482.

Richard, N., G. Mourente, S. Kaushik and G. Corraze. 2006. Replacement of a large portion of fish oil by vegetable oils does not affect lipogenesis, lipid transport and tissue lipid uptake in European seabass (Dicentrarchus labrax L.). Aquaculture 261:1077-1087.

Sargent, J. R. and A. G. J. Tacon. 1999. Development of farmed fish: a nutritionally necessary alternative to meat. Proc. Nutr. Soc. 58:377-383

Seo, J. Y., K. H. Choi, J. Choi and S. M. Lee. 2005. Effect of feeding frequency of extruded diets containing different macro-nutrient levels on apparent nutrient digestibility in grower flounder Paralichthys olivaceus. J. Aquac. 18:160-166.

Torstensen, B. E., J. G. Bell, G. Rosenlund, R. J. Henderson, I. E. Graff, D. R. Tocher, Ø. Lie and J. R. Sargent. 2005. Tailoring of Atlantic salmon (Salmo salar L.) flesh lipid composition and sensory quality by replacing fish oil with a vegetable oil blend. J. Agric. Food. Chem. 53:10166-10178.

Yoshimatsu, T., H. Imoto, M. Hayash, K. Toda and K. Yoshimura. 1997. Preliminary results in improving essential fatty acids enrichments of rotifer cultured in high diensity. Hydrobiologia 358:153-157. 